\title{
Eruptive history of Fuji Volcano from AD 700 to AD 1,000 using stratigraphic correlation of the Kozushima-Tenjosan Tephra
}

\author{
Makoto Kobayashi ${ }^{1}$, Akira Takada ${ }^{2}$ and Shun Nakano ${ }^{3}$
}

\begin{abstract}
Makoto Kobayashi, Akira Takada and Shun Nakano (2007) Eruptive history of Fuji Volcano from AD 700 to AD 1,000 using stratigraphic correlation of the Kozushima-Tenjosan Tephra. Bull. Geol. Surv. Japan, vol. 57 (11/12), 409-430, 14 figs, 1 table.
\end{abstract}

\begin{abstract}
We analyzed refractive index, microstructure, vesicularity of glass from an alien tephra in the upper weathered volcanic ash soil horizon of Fuji Volcano, Izu peninsula, Miyakejima, and Niijima Volcanoes. The glass size increases toward Izu Islands. Based on the vesiculality of glass, the Kozushima-Tenjosan tephra (AD 838) can be distinguished from the Niijima-Mukaiyama tephra (AD 886). Thus, we determined from where the tephra of low refractive index on the flank of Fuji Volcano comes from. Next, using the stratigraphic correlation of the tephra, the detailed stratigraphy of Fuji Volcano during the period of AD 700-1,000 was clarified. It was difficult to determine exact age of each eruption by ${ }^{14} \mathrm{C}$ dating with 2 sigma error bar (around \pm 40 years). However, the KozushimaTenjosan tephra horizon can classify Fuji Volcano products those below the tephra and those above the tephra. The Obuchi scoria (OBC), the Kansuyama scoria (KNS), the Nishi-Futatsuzuka scoria on S and SE flanks, the Takamarubi lava flow (Tam) and the Hinokimarubi 2 lava flow (Hnm 2), the scoria associated with the Oniwa-Okuniwa 2 lava flow (Onw 2) on NE and N flanks are below the Kozushima-Tenjosan tephra. The Fudosawa lava flow (Fud), the Obuchimarubi lava flow (Obu), the Higashi-Usuzuka south lava flow (Hum), the Mizugatsuka-hinokimarubi lava flow (Him) on S and SE flanks, the Kenmarubi 2 lava flow (Ken 2), the Tenjin-Igatono scoria (TNG), the Aokigahara lava flow and the Nagaoyama scoria on the NE and N flanks are above the Kozushima-Tenjosan tephra. The Kozushima-Tenjosan tephra was discovered just below the S-24-6 scoria on E flank. The stratigraphy of E flank is rearranged as follows in ascending order: the S-24-5 scoria, the S-24-5-1 scoria (newly defined), the S-24-5-2 scoria (newly defined), the S-24-5-3 scoria (newly defined), the Kozushima-Tenjosan tephra, the S-24-6 scoria, the S-24-7 scoria, the S-24-9 scoria, the S-24-10 scoria.
\end{abstract}

Keywords:Fuji Volcano, tephra, tephrochronology, the Kozushima-Tenjosan tephra, vesiculality, refractive index, Enryaku eruption, Jogan eruption

\section{Introduction}

Recent studies of Fuji Volcano based on mapping and trench surveys have revealed that dozens of monotonous eruptions occurred during the historical age (Yamamoto et al., 2005; Takada et al., 2007). In particular, these studies revealed that the activity around the $9-10^{\text {th }}$ century, including the Jogan eruption (AD 864-866), is the key to discuss the magma supply rate and the eruption mechanism because the direction of the fissures changed after this period. Therefore, accurate dating is required. However, the dates of the samples obtained by radiometric dating have a 2 sigma error of around \pm 40 years even after calibration. The calibration curve for this era is complicated, and the error in the correction value might increase. To over- come the fundamental problems with regard to the ${ }^{14} \mathrm{C}$ dating in this era, we employed the stratigraphy of a tephra, the age of which is fairly restricted according to historical literatures. This tephra is of a thin silicic type and is widely distributed at the horizon of the $9^{\text {th }}$ century. It is considered to have originated in the Kozushima-Tenjosan tephra (AD 838) and/or the Niijima-Mukaiyama tephra (AD 886); ages of both these tephra can be found in historical literatures. Uesugi (2003) suggested that this tephra originated from the Izu islands (Kozushima and Niijima) because the weathered volcanic ash soil includes the pumicetype volcanic ash shards with low refractive indices similar to those of Izu islands origin. However, the origin of the tephra remains unclear.

In this study, the origin of the thin silicic tephra of

\footnotetext{
${ }^{1}$ Dia Consultants Co., Ltd., Yoshino-cho 2-272-3, Kita-ku, Saitama 331-8638, Japan.

${ }^{2}$ Geoinformation Center, GSJ.

${ }^{3}$ Institute of Geology and Geoinformation, GSJ.
} 
the $9^{\text {th }}$ century horizon is investigated on the basis of its morphological characteristics. We observed the grain size of the volcanic glass, and observed its microstructure and vesicularity by using an optical microscope and an electron microscope, respectively. From our investigations, we concluded that the volcanic glass with a low refractive index originated from the Kozushima-Tenjosan eruption in AD 838. Based on this data, we classified the relationship between certain lava flows of Fuji Volcano during the last 2,000 years and the tephra horizon.

This study was carried out as one of the promotional projects of the Ministry of Education, Science, and Technology. The overview of these projects is shown by Takada et al. (2004). The names of the layers of Fuji Volcano used in this study are the same as those stated in Tsuya (1968), Machida (1977), Uesugi (1990, 1993, 1998, and 2003), and Miyaji (1988).

\section{Analytical methods}

\subsection{Samples}

Since the volcanic glasses found around Fuji Volcano were all air-fall ash origin, we selected some air-fall ash samples for analysis. The air-fall tephras were sampled at the region between Higashi-Izu, Hakone and Fuji Volcano (Figure 1). The Kozushima-Tenjosan and the Niijima-Mukaiyama tephras that were detected in an outcrop at Miyakejima were used as reference samples. In this section, the stratigraphy of around the $9^{\text {th }}$ century in the region is reviewed and the sampling points are shown.

\subsubsection{Izu island (in Miyakejima, Oyama)}

Figure 1 shows the sampling point in Miyakejima. According to Tsukui and Suzuki (1998) and Tsukui (1999), the Kozushima-Tenjosan tephra is $5 \mathrm{~cm}$ thick and is obserred tobe a white rhyolitic air-fall layer within black soil. This layer sometimes contains pumices having a diameter of up to $10 \mathrm{~mm}$. On the other hand, the Niijima-Mukaiyama tephra is an air-fall layer that is observed above the Kozushima-Tenjosan and Miyakejima tephras. The Niijima-Mukaiyama tephra is observed to be a white layer of several centimeters thick within yellowish-brown weathered volcanic ash soil, and it contains several white pumiceous fragments with diameters of up to $10 \mathrm{~mm}$. We analyzed the volcanic glasses collected from the Kozushima-Tenjosan and the Niijima-Mukaiyama tephras.

\subsubsection{Fuji Volcano (in Gotenba city, Tarobo)}

Miyaji et al. (1992) and Uesugi (2003) showed the detailed columnar section of Tarobo (041126-1) near the trek to the summit of Mt. Fuji (altitude: $1440 \mathrm{~m}$ ) (Figure 1 and 2), where the tephra from Younger Fuji Volcano outcrops continuously. At this point, the Hoei tephra (Ho), the Nishi-Futatsuzuka scoria (NFT), the Akatsuka scoria (AKT) and the Futatsuzuka scoria
(FTT) can be observed from above (Figure 3). Since volcanic glasses originating from widespread tephra were detected to wash and to sieve weathered volcanic ash soil samples, several volcanic glasses with low refractive indices were detected in the area between the lower part of Ho and NFT. We collected the glasses in the horizon between Ho and NFT.

\subsubsection{Hakone Volcano (in Hakone town, Ubako)}

Figure 1 shows the sampling point in Hakone Volcano.

The volcanic deposit of the Kanmurigatake pyroclastic flow $(2,900 \pm 100$ yBP; Oki and Hakamata, 1975) was considered to be the last volcanic deposit of Hakone Volcano. However, a recent study showed that there exist five layers of pyroclastic surge and air-fall deposits of the phreatic eruption after the pyroclastic flow deposit of Kanmurigatake around Owakidani (Kobayashi et al., 2006). These layers are as follows in ascending order: the Zunasawa scoria ( $\mathrm{Zu}$ ) and the S18 scoria (S18) from Fuji Volcano; the secondary lahar layer that originated from the Owakidani tephra 1 (Hk-Ow1) and the Owakidani tephra 2 (Hk-Ow2); the air-fall ash layers, called as the Owakidani tephra 3 (Hk-Ow3) and the Owakidani tephra 4 (Hk-Ow4); and the Owakidani tephra 5 (Hk-Ow5) at the sampling point (Owakidani; Hk1, Ubako; Hk2; Figure 1). The volcanic glass layer with a low refractive index is identified as that under Hk-Ow3 (Kobayashi et al., 2006). We analyzed the volcanic glasses collected from immediately beneath Hk-Ow3.

\subsubsection{Higashi-Izu Omuroyama Volcano (in Ito city)}

The sampling point around Higashi-Izu Omuroyama Volcano is shown in Figure 1. According to Sugihara (1984) and Sugihara et al. (2001), around the HigashiIzu area, the ground surface is composed of black soil, intercalated with a layer of white and glassy volcanic ash (Kozushima-Tenjosan tephra) having a thickness of $5 \mathrm{~cm}$. At the sampling point (OM1), we observed the Omuroyama scoria (3,700 \pm 100 yBP; Saito et al., 2003), the Iwanoyama tephra (2 ka; Hayakawa and Koyama, 1992), and white air-fall volcanic ash (volcanic sand to silt), in ascending order. In the Higashi-Izu area, we only identified a layer of glassy ash, and no fall units were recognized within the layer. This implies that either the Niijima-Mukaiyama tephra or the Kozushima-Tenjosan tephra have reached the area around the Higashi-Izu region. Furthermore, this implies that the tephra layers originated from a single eruption column and thus the volcanic glass must exhibit identical traits.

\subsection{Analysis of tephra}

The purpose of the analysis is to verify whether the volcanic glass came from the Izu Islands and to identify its origins. For this, we measured the diameter of the volcanic ash grain and analyzed the microstructure and vesicularity of the glasses. We also measured the refractive index of the glasses. 


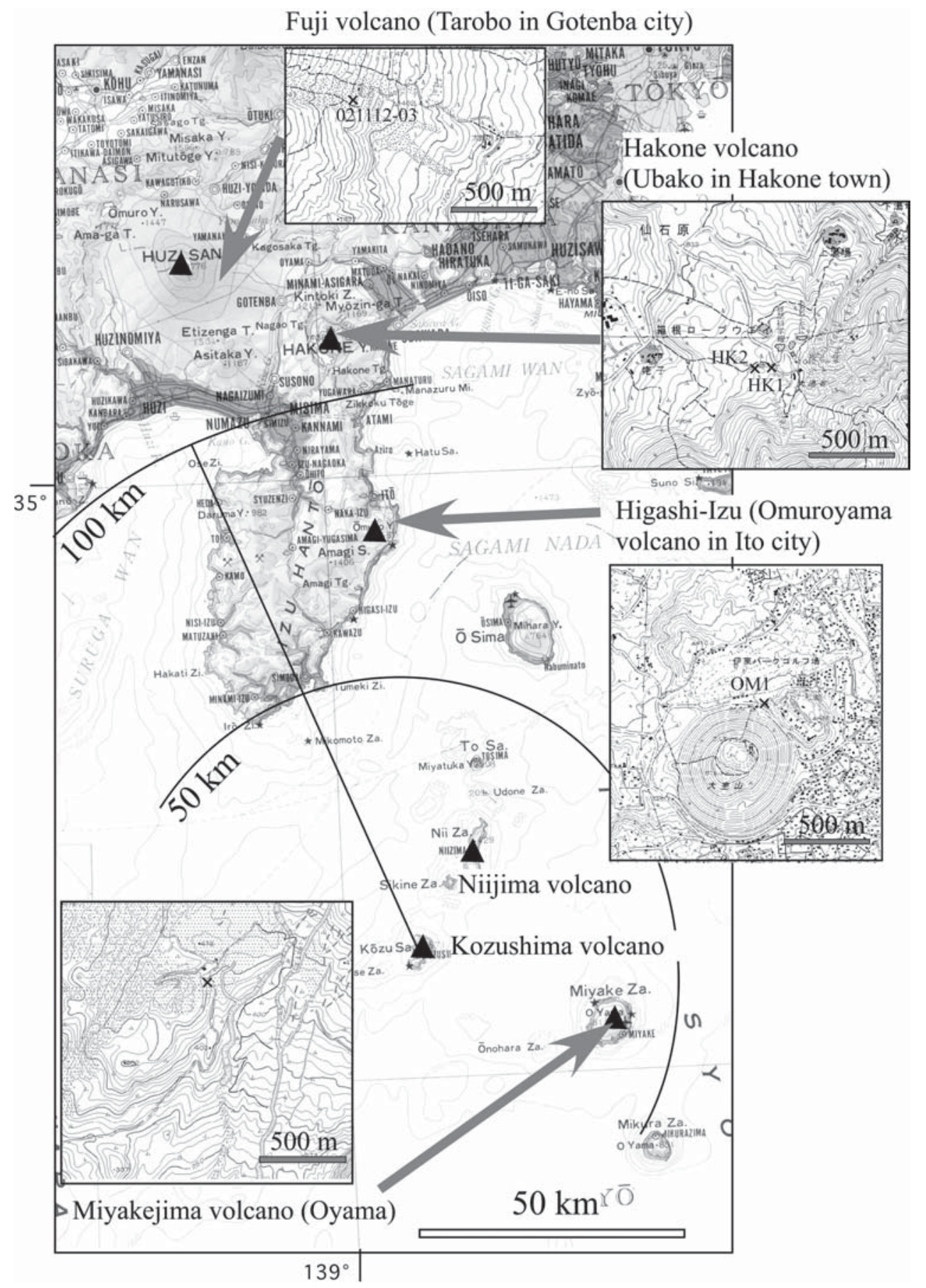

Fig. 1 Map of Fuji Volcano and adjacent area with sample localities to identify Kozushima-Tenjosan tephra. The base maps are the 1:500, 000 scale and the 1:50,000 scale topographic maps of GSI.

\subsubsection{Measurement of diameter}

We employed mesh methods for the analysis. The sample screened by a mesh was used for measuring the diameter of the volcanic glasses. The weight ratio at each mesh was calculated. The maximum average diameter was calculated as the averaged value of 2 to 10 grains. 2.2.2 Analysis of vesicularity

We prepared a slide by fixing very fine grains on the slide glass with epoxy resin. During the preparation, we decompressed this slide to $10 \mathrm{~Pa}$ by using a vacuum pump in order to eliminate the bubbles present between the glass and the sample. We polished this sample using $\# 3,000$ carborundum and checked the appearance of the surface using a polarization microscope. We selected the sample that exhibited a clear formation of vesicularity on its surface and polished it further using the $1 \mu \mathrm{m}$ diamond paste. The polished samples were covered with carbon and we obtained their reflected images using a 
scanning electron microscope (SEM). These images are exploited to observe the surface formations and vesicular microstructure of volcanic glasses. On the other hand, we traced the outline of the glasses and the bubbles by using image processing and illustration software. First, the glass was colored white and the bubbles were colored black in the traced drawing. The image processing software then converted the images into monochrome and deduced the ratio of the colored area. This ratio represented the vesicularity of the sample.

\subsubsection{Measurement of refractive index}

The refractive index measurement system using the thermal immersion method "MAIOT" (Furusawa, 1995), which directly measures the temperature of immersion oil, was used for measuring the refractive indices. The measurement accuracy is approximately 0.0001 for volcanic glass. Thirty grains of volcanic glass were measured to obtain the distribution of their refractive indices.

\subsubsection{Air-fall ash horizon / Stratigraphy}

We sampled the soil or weathered volcanic ash soil at $5-15 \mathrm{~cm}$ intervals at the outcrop and defined the horizon which has higher concentration of volcanic glasses. The pretreatment of the analysis was based on the method of Furusawa (2003). The samples were sifted in order to fix the grain size in the diameter 1/8-1/16 mm. Initially, we washed the grains in flowing water using \#250 disposable nylon mesh. Moreover, we sifted the remaining samples using \#125 disposable nylon mesh in water. Subsequently, we prepared the slide with a light cure resin whose refractive index is 1.545 . We selected glasses and pumices from 1,000 grains, measured their refractive indices, and plotted the histogram of their refractive indices. The distribution of the number of grainsódivided into groups with the same refractive indexóis expressed as the number of grains in every 1,000 grains (\%).

\section{Identification of the Kozushima -Tenjosan tephra}

\subsection{Analysis results}

The analysis results are shown in Table 1.

The diameter of the glass shard decreases as the distance from Niijima or Kozushima increases. The maximum average grain sizes are as follows: $1.71 \mathrm{~mm}$ at Miyakejima, which is at a distance of about $36 \mathrm{~km}$ from Kozushima; $0.57 \mathrm{~mm}$ at Higashi-Izu Omuroyama Volcano, which is distant about $77 \mathrm{~km} ; 0.24 \mathrm{~mm}$ at Hakone Volcano, which is at a distance of $115 \mathrm{~km}$; and $0.13 \mathrm{~mm}$ at Fuji Volcano.

Under the optical microscope, all of the volcanic glass samples appeared transparent and their structure was mainly of the pumice type (Machida and Arai, 1992, 2003); furthermore, some of the ashes appear to be poorly vesiculated. Under the scanning electron microscope, the bubble structures of the volcanic glasses were found to be either of the sponge-type or fiber-type. The diameter of the bubbles is approximately 20-300 $\mu \mathrm{m}$.

The result of the refractive index measurements revealed that there was no clear difference among the refractive indices of the samples and their values were approximately 1.494-1.497.

There were apparent differences between the vesicularities of the Kozushima-Tenjosan and the NiijimaMukaiyama tephras. The Niijima-Mukaiyama tephra, which was sampled in Miyakejima, has a void fraction of $28 \%$. On the other hand, the void fraction of the Kozushima-Tenjosan tephra was $37 \%$. Therefore, the vesicularity of the tephra might be a logical criterion to distinguish between these two tephras. The Kozushima-Tenjosan tephra sometimes includes highly vesiculated volcanic glass having a void fraction of 50 $\%$ and thus the average void fraction would be higher than that of the Niijima-Mukaiyama tephra (more than $35 \%)$. The average vesicularity of the volcanic glass sampled at Fuji Volcano, Higashi-Izu Omuroyama and Hakone Volcano was significantly greater than $30 \%$. The average vesicularity was $34 \%$ at Fuji Volcano and $38 \%$ at Higashi-Izu Omuroyama. The value was slightly smaller, $32 \%$ at Hakone Volcano.

We plotted the histogram of the void fractions of the sampled volcanic glass from each sampling point at the Niijima-Mukaiyama and the Kozushima-Tenjosan tephras in Miyakejima. A careful observation of this histogram reveals that most volcanic glasses in the Niijima-Mukaiyama tephra have a void fraction of 15$40 \%$. The Kozushima-Tenjosan tephra comprises glasses of 30-55\%. Generally, the distribution of other samples is scattered; however, the glasses at Fuji Volcano and Higashi-Izu Omuroyama are frequently observed on the high void fraction side. This implies that these glasses originate from the Kozushima-Tenjosan tephra. The glasses at Hakone Volcano have a void fraction of 20-40\% and indicate no clear inclinations. Moreover, there was no volcanic glass with low void fraction (15-20\%) and the samples are distributed around the high void fraction region. This also implies that the glasses at Hakone Volcano originate from the Kozushima-Tenjosan tephra. Finally, we concluded that the stratigraphically only a single layer was detected because the volcanic glasses with the same characteristics and formation have only one peak in the distribution of the numbers.

\subsection{Identification of the Kozushima-Tenjosan tephra}

White colored volcanic ash layers with fine white glasses in the horizon appear in the Shizuoka plain around Izu-Oshima and the Izu peninsula (Sugihara, 1984; Shizuoka Prefecture buried cultural property investigation laboratory, 1991; Hayakawa and Koyama, 1992). These volcanic glasses are considered to be airfall tephras from the Kozushima-Tenjosan eruption (Kozushima-Tenjosan tephra) based on the analyses of 


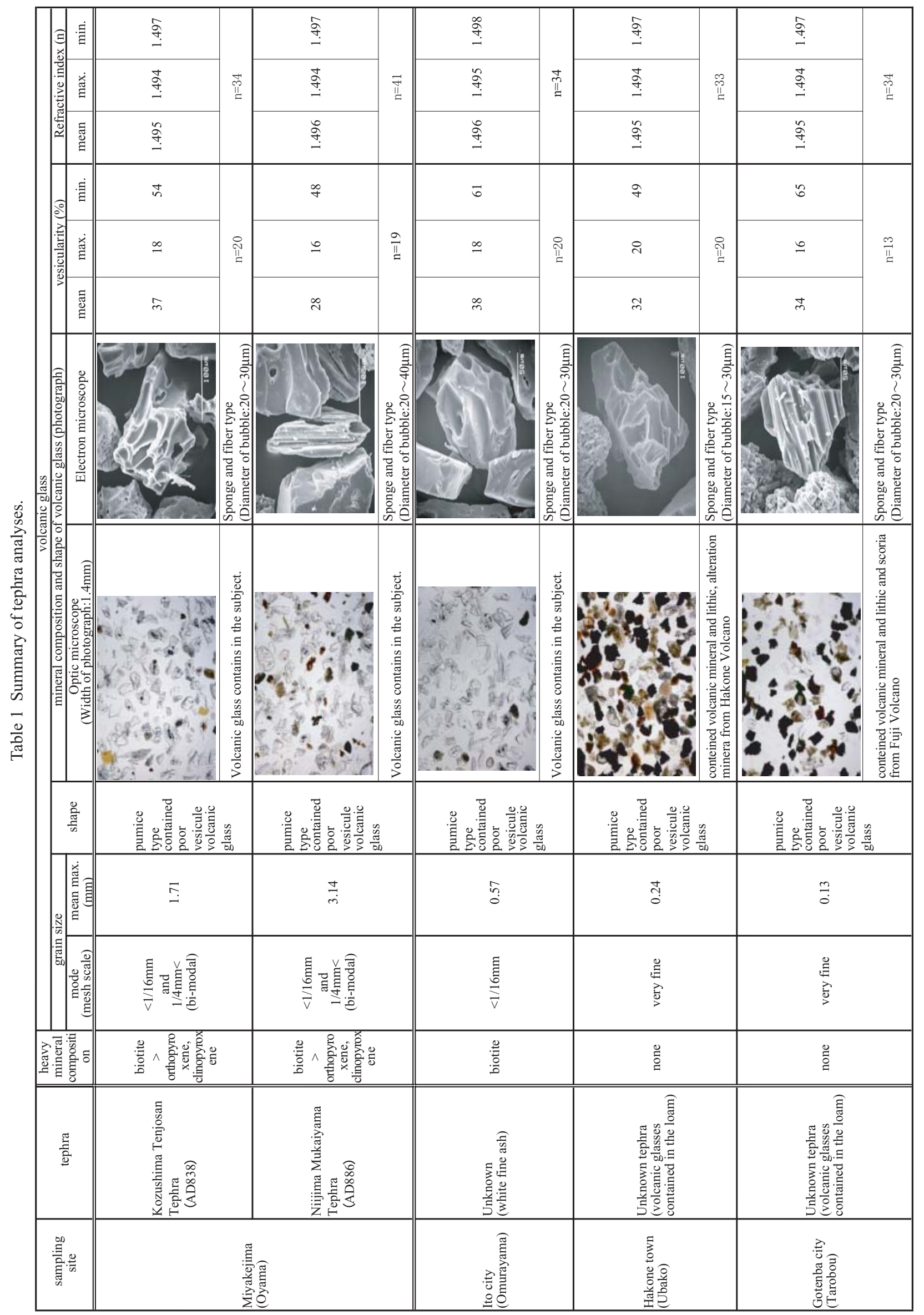


the minor components of the volcanic glasses (Shimada et al., 1998; Sugihara and Shimada, 1998) and the historical literatures (Koyama and Hayakawa, 1996). This volcanic glass was found in Hakone Volcano. Volcanic glasses with low vesicularity and low refractive index were identified in the weathered volcanic ash soil around the foot of Fuji Volcano, although the glass cannot be observed with the naked eye (Uesugi, 2003). As the air-fall ash horizon is one layer, these glasses are considered to originate only from the KozushimaTenjosan eruption (AD 838) or the Niijima eruption (AD 886). Although the difference between the volcanic glasses from the two eruptions cannot be distinguished, a study of their microstructures revealed the difference in their vesicularities. In addition, we confirmed that the effective criterion to distinguish both the tephras is the distribution of the vesicularity of the volcanic glasses. The volcanic glasses with low refractive index that are found around Fuji Volcano may have origins in the Kozushima-Tenjosan tephra. Sugiuchi and Fukuoka (2005) showed that the volcanic glasses in our study originated from the Kozushima-Tenjosan tephras on the basis of the analysis of the bulk rock using a microprobe, which revealed the main components of the tephras. On the basis the overall results of the vesicularity analysis, discussion of the historical literatures, and chemical analysis of the glasses, the volcanic glasses with low refractive indices are considered to originate in the Kuzushima-Tenjosan tephra.

As described below, the volcanic glasses with low refractive index lie under the Aokigahara lava flow, which extruded when the Jogan eruption occurred in AD 864. The volcanic glasses with low refractive index were not found when the Nagaoyama scoria cone, which formed in the same eruption, was investigated using the trench excavation survey. These facts strongly suggest that the volcanic glasses with low refractive index are stratigraphically older than the KozushimaTenjosan tephra.

\section{Stratigraphy at the foot of Fuji Volcano}

The transparent pumice-type volcanic glasses or the low vesicularity and low refractive index volcanic glasses, which were detected in the horizon around the foot of Fuji Volcano, are considered to originate from (or are identical to) the Kozushima-Tenjosan tephra. We analyzed the eruptive deposits from Fuji Volcano produced at around AD 838 (Figure 2) to determine whether the ash-fall horizon of the Kozushima-Tenjosan tephra lies at the upper level or lower level of this horizon.

We sampled the weathered volcanic ash soil and the soil above and below the targeted volcanic deposit at intervals of $5-15 \mathrm{~cm}$. We then observed the microstructure and measured the refractive index of the volcanic glasses in the sample. For the volcanic glasses with low refractive index, the content (the number of volcanic glass particles present per 1,000 particles) was measured. We considered the horizon of the maximum content to be the ash-fall horizon of Kozushima-Tenjosan. The sampling at the trench excavation and outcrop survey was conducted on a relatively flat and smooth topography. This sampling minimized the contamination from secondary deposits. The secondary movement associated with bioturbation might have occurred. However, it is reasonable to define the maximum level as the ash-fall horizon because the dispersal of ash within the soil is considered to take place in a manner similar to diffusion.

\subsection{On the southern flank of Fuji Volcano}

\section{Correlation with the Obuchi scoria (OBC)}

The Obuchi scoria (OBC; Miyaji, 1988) has its source in the surrounding area of Kita-Takahachiyama (Takada and Kobayashi, 2007). In the Takahachi parking area south (031029-03), talus deposit and OBC, which are intercalated with weathered volcanic ash soil, are observed in descending order (Figures 2 and 3). Ten samples were obtained from the weathered volcanic ash soil and the talus deposit. The results of their analysis reveal that the content ratio of pumice-type volcanic glasses increases as the sampling level moves downward from the top to the level immediately above OBC. The maximum content rate was $48.0 \%$ at the level immediately above OBC. In this location, several volcanic glasses were block-type glasses with low vesicularity or pumice-type glasses. Within the horizon, trace amounts of biotite and quartz were also detected along with the volcanic glass. The refractive index of the volcanic glasses lies in a fairly narrow range of 1.495-1.497.

To the north of a farm road in Tensho-Kyosya (031029-4), fluvial deposits, OBC, the Yufune-2 scoria (Yu-2), the A or the D scoria (Takada and Kobayashi, 2007), the Zugasawa scoria ( $\mathrm{Zu})$ are found with intercalated layers of weathered volcanic ash soil in the descending order. The weathered volcanic ash soil intercalating $\mathrm{OBC}$ and fluvial deposit were measured. The pumice-type volcanic glasses are present in the upper level of the fluvial deposit and the level immediately above OBC. The maximum content of $35.0 \%$ was recorded. The glasses observed in this horizon were block-type glasses with low vesicularity or pumice-type glasses with low vesicularity. The refractive index of the volcanic glasses lies in a fairly narrow range of 1.495-1.497.

The volcanic glasses from the two outcrops described above are considered to originate in the KozushimaTenjosan tephra because the glasses were of the pumice-type and have a low refractive index. It is concluded that $\mathrm{OBC}$ erupted prior to the Kozushima-Tenjosan tephra. 


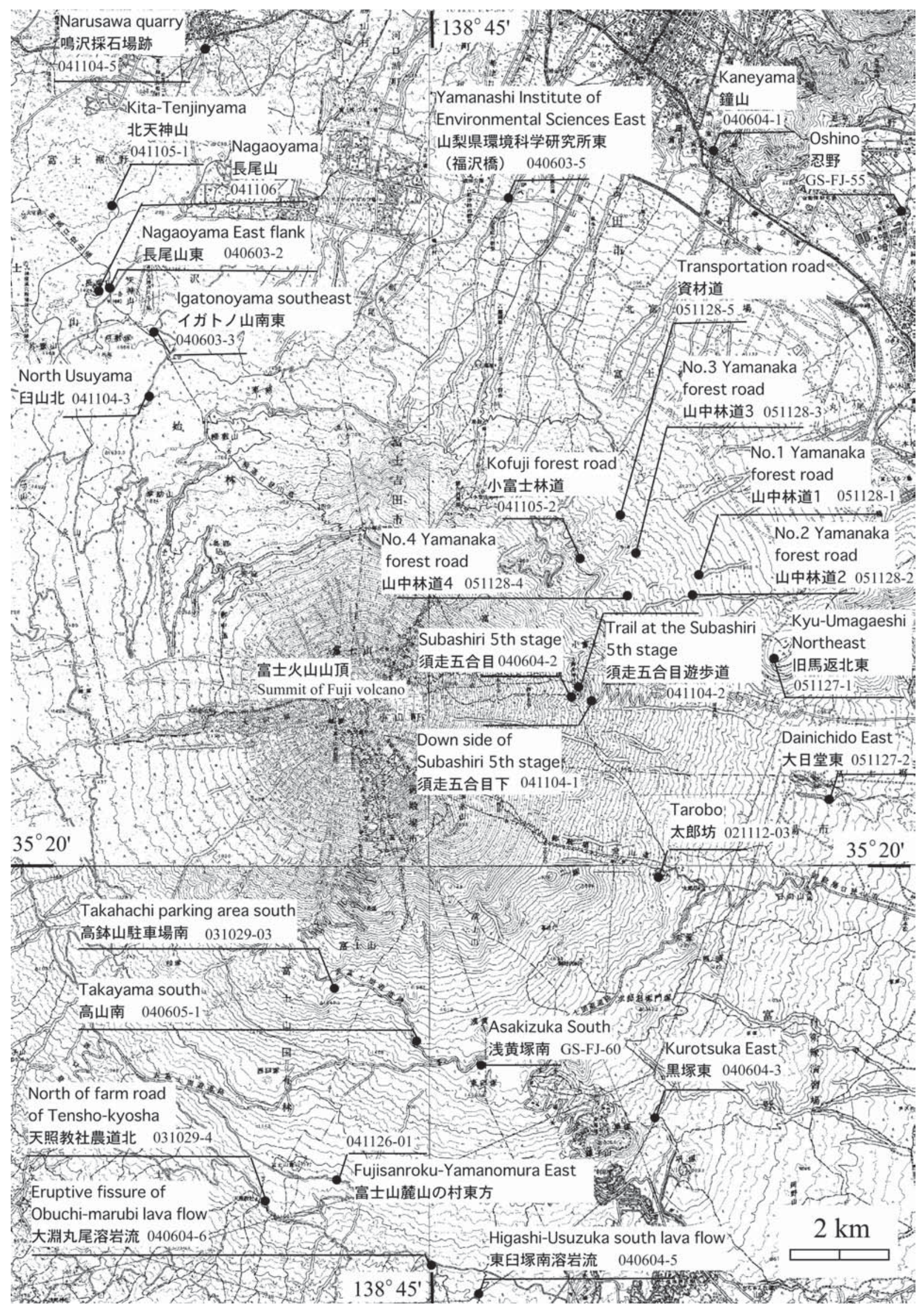

Fig. 2 Locality map of trench sits and outcrops on the flank of Fuji Volcano. 


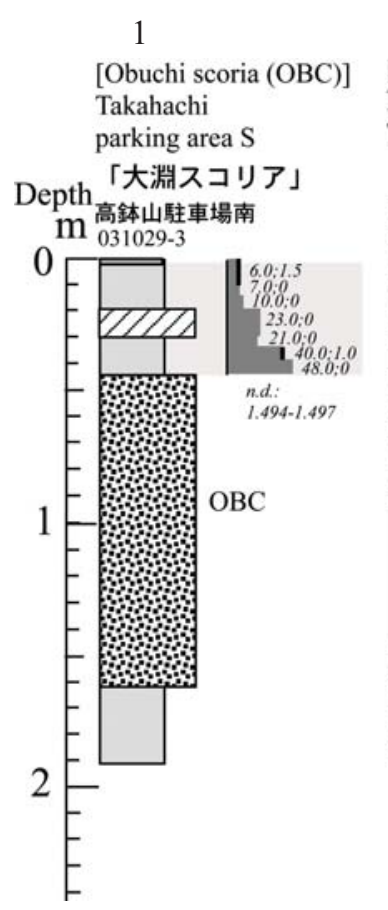

2

[Obuchi scoria $(\mathrm{OBC})]$

$\mathrm{N}$ of farm road of

Tensho-kyosha

「大淵スコリア」

天照教社農道北

031029-4

6

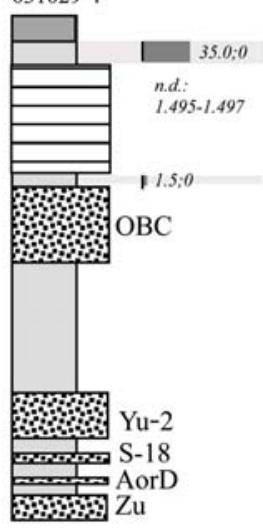

[Fudosawa lava]

Fujisanroku

-yamanomura E

「不動沢溶岩」

富士山麗山の村東

041126-1

Pudosawa

$\bigoplus$ lava

1201C-1:

$\bigoplus \begin{gathered}A D \text { 970- } 1040 \\ (1020 \pm 40 y B P\end{gathered}$

皿

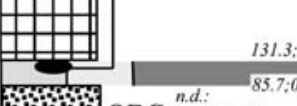

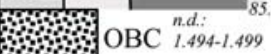

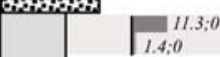

Ex内.
4

[Fudosawa lava] [Obuchimarubi lava]

Takayama S around eruptive fissure

「不動沢溶岩」「大淵丸尾溶岩」

高山南吙周辺

040604-5 040604-6 Obuchimarubi

\#落 Fudosawa 0

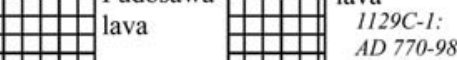

n.d: $1.497{ }_{(1170 \pm 40 y B P}$

10.3.0 $1040604 \mathrm{C}-1$

10:0 $A D 790-1000$

$27 \mathrm{OBC}$

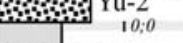

Fistis S-18

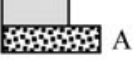

$$
\text { . }
$$

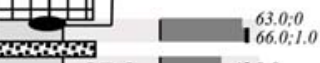

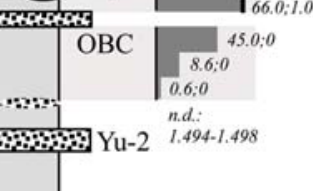

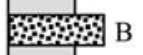

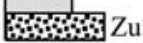

9

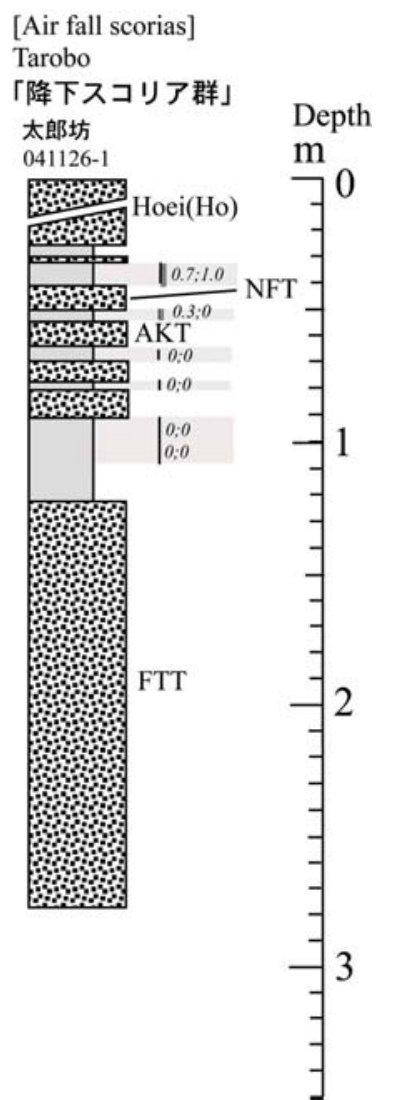

Fig. 3 Columnar sections of trench sites and outcrops on the S to SE flank of Fuji Volcano.

\section{Correlation with the Fudosawa lava flow (Fud)}

In Fujisanroku-Yamanomura east (041126-01), pumice-type volcanic glasses with fairly low vesicularity were detected in the weathered volcanic ash soil be- tween the Fudosawa lava flow (Fud; Tsuya, 1968) and $\mathrm{OBC}$, and the level below OBC (Figures 2 and 3). The content ratio of the glasses increases as the sampling level moves upward. The maximum value of $131.3 \%$ was recorded at the level immediately below Fud. The 
refractive index of the volcanic glasses lies in the range of 1.496-1.499. The microstructure and refractive index of the volcanic glasses indicates that they could be considered to have originated in the KozushimaTenjosan tephra. However, the refractive index of the glasses exhibits a slightly upper trend. In this study, we consider that the detected volcanic glasses originate in the Kozushima-Tenjosan tephra on the basis of the fact that no qualified main tephra have been found other than the Kozushima-Tenjosan tephra.

In Takayama south (040605-1), a small amount of volcanic glasses were detected in the level only between Fud and OBC. The detected glasses had low vesicularity and their refractive index was 1.497 . The characteristics of the volcanic glasses indicate that they originated from the Kozushima-Tenjosan tephra.

The volcanic glasses that originated from the Kozushima-Tenjosan tephra were detected in the level between Fud and OBC. Based on this, it is assumed that Fud erupted after the Kozushima-Tenjosan tephra.

\section{Correlation with the Obuchimarubi lava flow (Obu)}

In the area around the eruptive fissure (Takada et al., 2007) of the Obuchimarubi lava flow (Obu; Tsuya, 1968) at an altitude of $940 \mathrm{~m}$ (040604-06), volcanic glasses were detected in the level between the $\mathrm{Obu}$ and $\mathrm{OBC}$, and the level below OBC (Figures 2, 3, and 5). The content ratio of the volcanic glasses increases as the sampling level moves upward. The maximum value of $66.0 \%$ was obtained at the horizon immediately above OBC. The refractive index of the volcanic glasses lies in the range of 1.494-1.498. The characteristics of the volcanic glasses indicate that they originate in the Kozushima-Tenjosan tephra, since the peak horizon of the content of the volcanic glasses was at the level above OBC. This indicates that Obu erupted after the Kozushima-Tenjosan tephra. Meanwhile, the volcanic glasses detected in the level below OBC are considered to originate from the secondary movement of the Kozushima-Tenjosan tephra.

\section{Correlation with the Higashi-Usuzuka south lava flow (Hum)}

At the outcrop (040604-05) of the Higashi-Usuzuka south lava flow (Hum; Takada et al., 2007) at an altitude of approximately $910 \mathrm{~m}$, volcanic glasses were detected in the level below Hum (Figures 2 and 3). The content rate of the volcanic glasses increases as the sampling level moves upward, and the maximum value of $20.6 \%$ was measured at the level immediately below Hum. All detected glasses were pumicetype glasses with low vesicularity. The refractive index was in the range of 1.499-1.502 in the higher mode, and 1.494-1.497 in the lower mode. The characteris- tics of the volcanic glasses in the lower mode level indicate that they originate in the Kozushima-Tenjosan tephra. The peak of the content rate was measured at the level above the Zunasawa scoria ( $\mathrm{Zu}$ ) (Miyaji, 1988). Among the volcanic glasses originating in the Kozushima-Tenjosan tephra, the maximum value was measured at the level immediately below Hum; therefore, Hum is considered to have erupted after the Kozushima-Tenjosan tephra. Meanwhile, the higher peak of the refractive index accounts for the Kawagodaira tephra (Machida and Arai, 2003).

\section{Correlation with the Mizugatsuka-hinokimarubi lava flow (Him)}

The outcrop (GS-FJ-60) of Asakitsuka south, is placed to the west of the Mizugatsuka-hinokimarubi lava flow (Him; Tsuya, 1968). Volcanic glasses were detected in the level immediately below this lava flow (Figures 2 and 3). The detected glasses had low vesicularity and their refractive index was in the range of 1.494-1.496. The microstructure and refractive index of the volcanic glasses, the geological condition of the surrounding area, and the results from the study indicate that these volcanic glasses originate in the Kozushima-Tenjosan tephra. The volcanic glasses that originated in the KozushimaTenjosan tephra were detected in the level immediately below Him. Therefore, the eruption occurred after the Kozushima-Tenjosan tephra.

\section{Correlation with the Kansuyama scoria (KNS)}

At the outcrop (040604-03) in Higashifuji-Enshujyo, to the east of Kurotsuka, volcanic glasses were detected in the weathered volcanic ash soil that covers the Kansuyama scoria (KNS) (Miyaji, 1988) (Figures 2 and 3 ). The maximum content rate of volcanic glasses was $28.3 \%$. All volcanic glasses detected were of the pumice-type with low vesicularity. The refractive index of the volcanic glasses was in the narrow range of 1.4941.497. The microstructure and refractive index of the volcanic glasses, the geological condition of the surrounding area, and the results indicate that these volcanic glasses originate in the Kozushima-Tenjosan tephra.

With regard to the volcanic glasses originating in the Kozushima-Tenjosan tephra, the peak of the content rate of the glasses was obtained at a level slightly above that for KNS. This leads to the assumption that KNS erupted after the Kozushima-Tenjosan tephra.

\subsection{On the eastern flank of Fuji Volcano}

On the eastern Subashiri flank, the existence of several scorias between the Hoei tephra (Ho) and the Yufune-2 scoria (Yu-2) has been reported (Uesugi, 2003). This study identified eight scoria layers that cover a broad range and are considered to be easily 

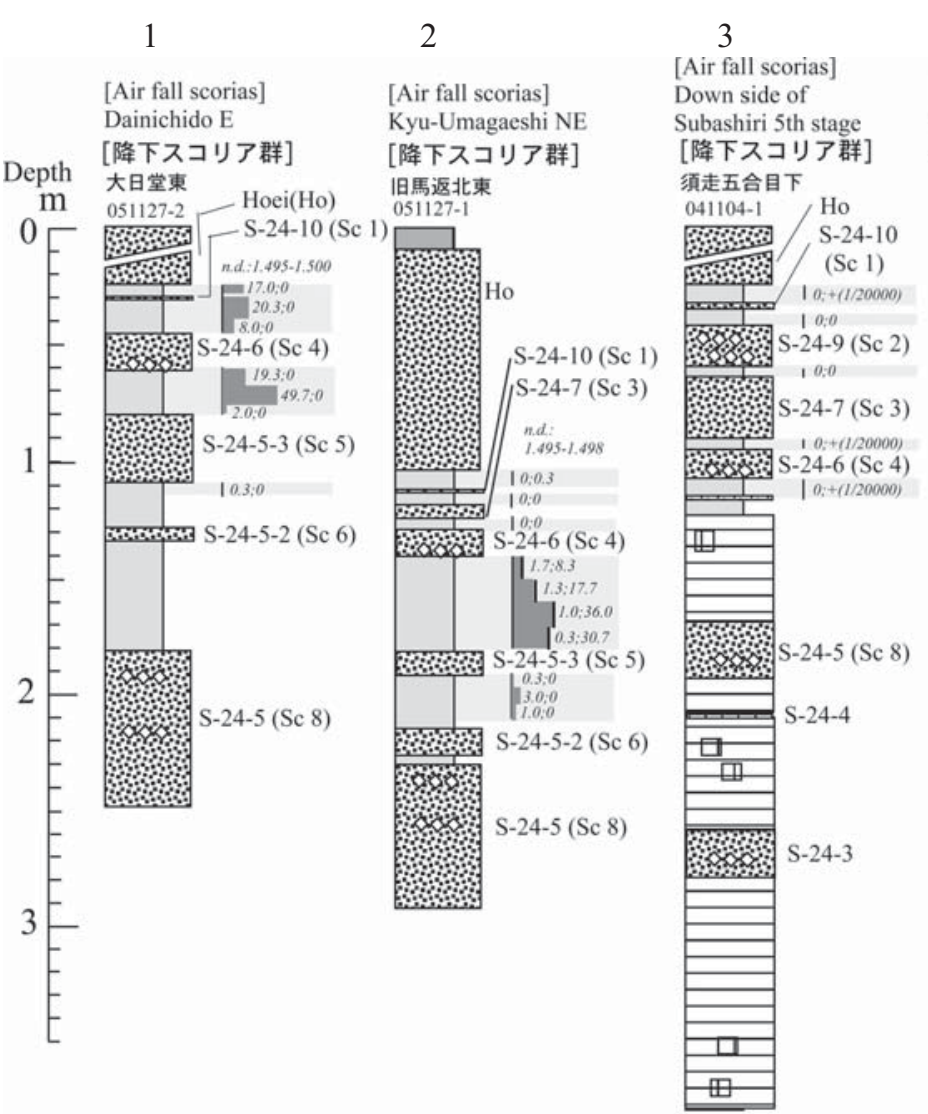

7

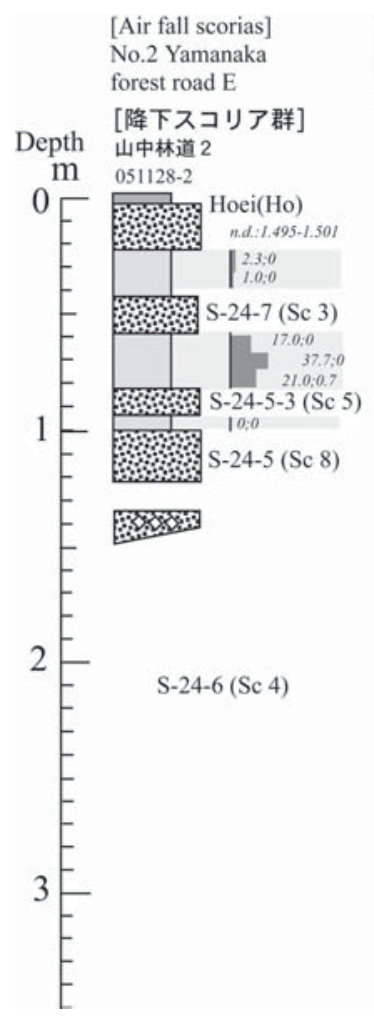

4

[Air fall scorias] Subashiri 5th stage

[降下スコリア群]

須走五合目

040604-2

\%ल

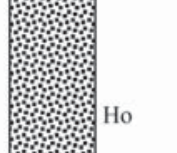

Ho
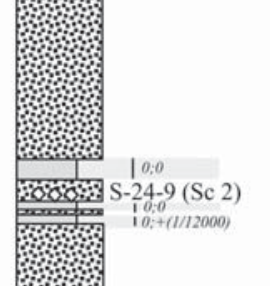

5

[Air fall scorias]
Trail at the Subashiri 5th stage

[降下スコリア群]

須走五合目遊步道 Depth

041104-2

एकस $\mathrm{Ho}$ S-24-10 $\mathrm{m}$

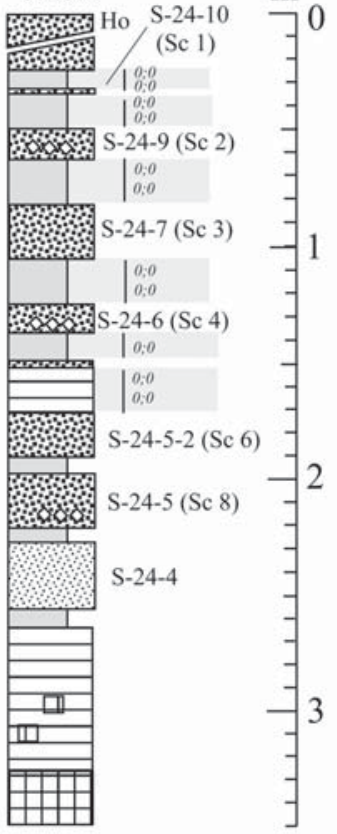

$A D 790-1000$

$(1130 \pm 40 \mathrm{yBP})$

$\mathrm{S}-24-7(\mathrm{Sc} 3)$
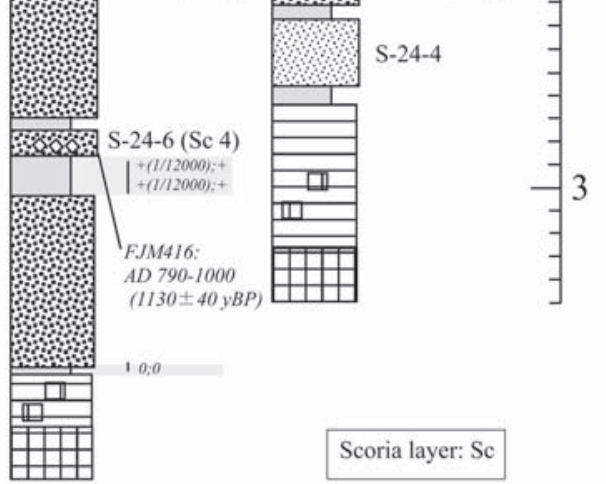

Scoria layer: Sc

9

10

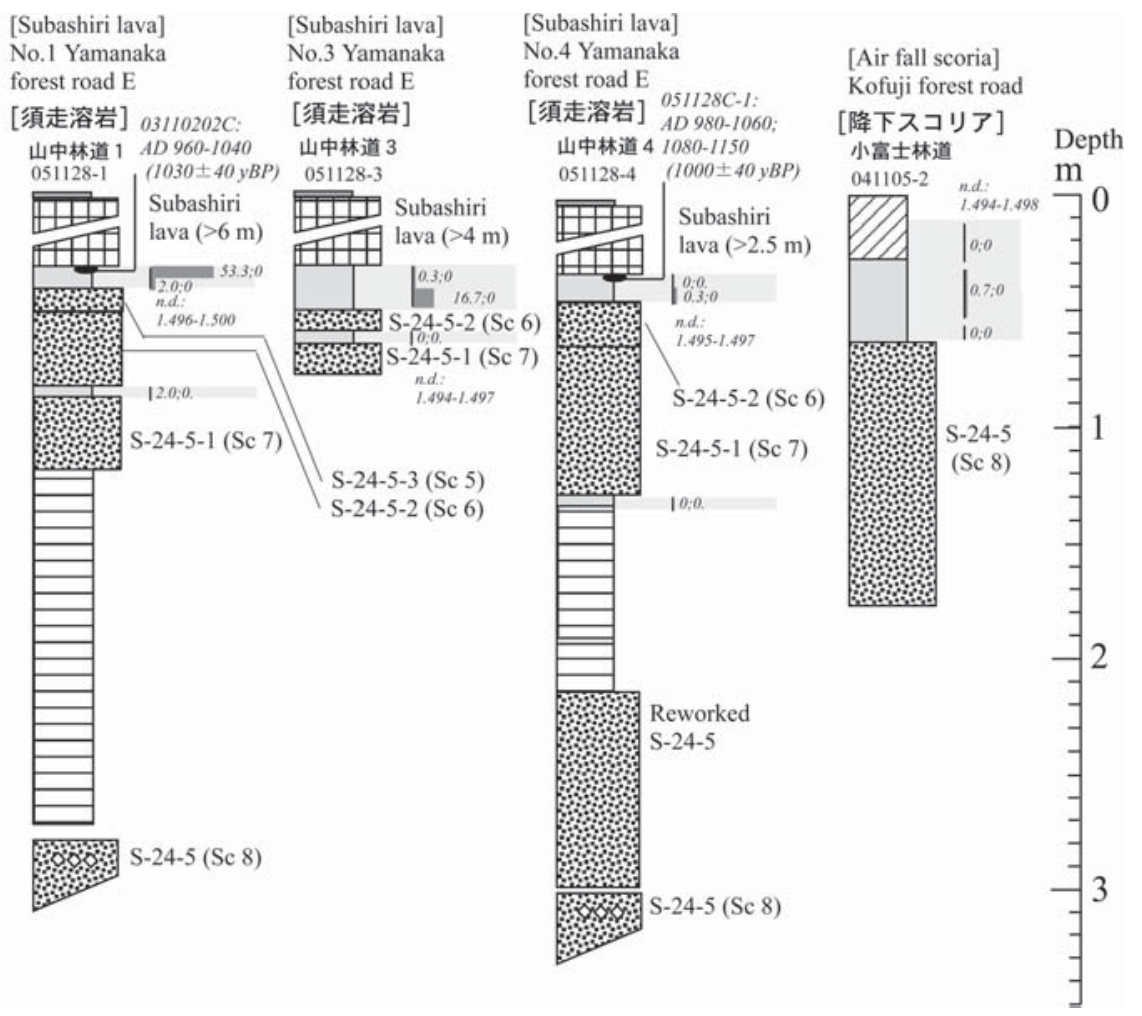




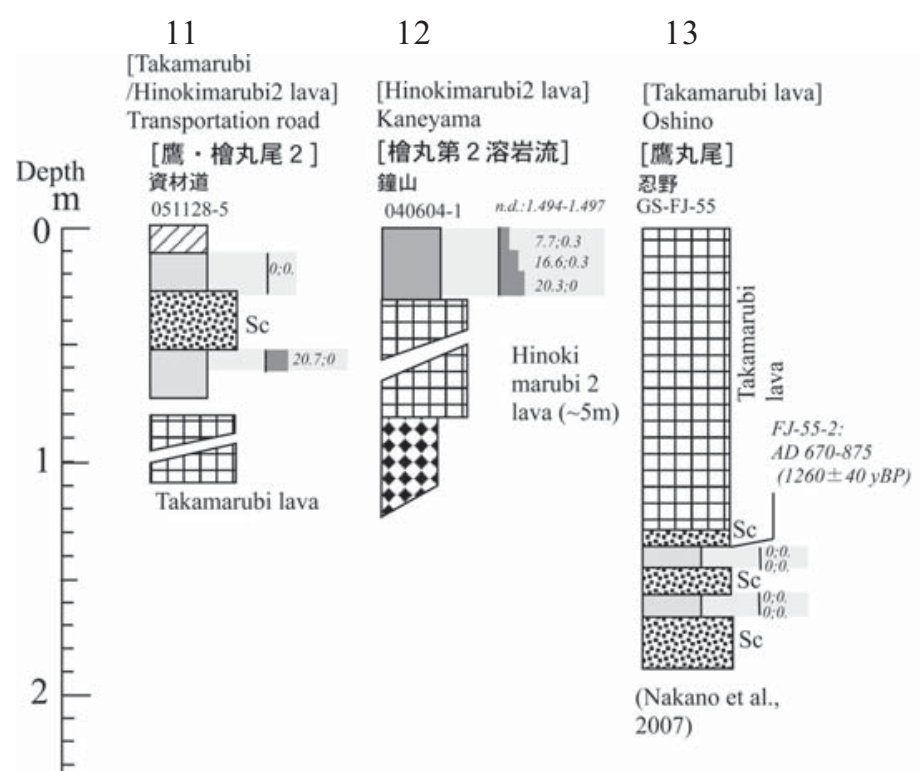

14
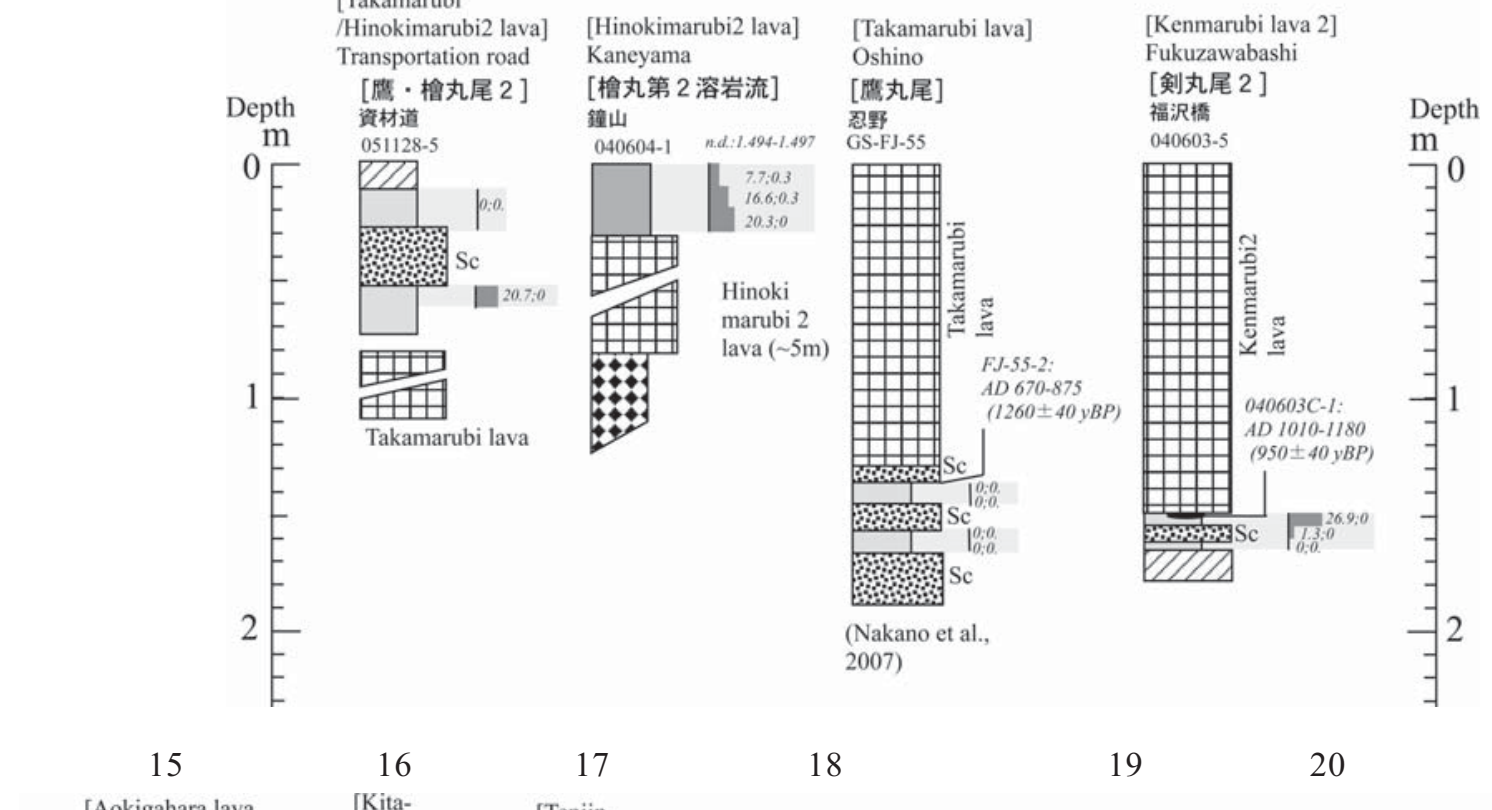

15

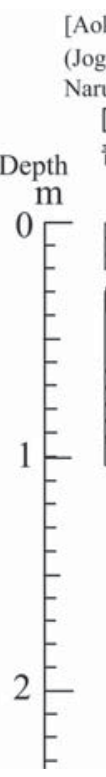

16

[Kita-

Aokigahara lava

(Jogan eruption AD864)]

Narusawa quarry

[貞観864

青条ヶ原溶岩]

鸣沢

曲地
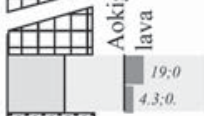

Karumizu
forest road

[北天神火口]

17

軽水林道

041105-1

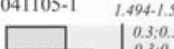

[Tenjin-

Igatonoyama]

Otawa forest road SE

[天神イガドノ山]

イガドノ南東

040603-3

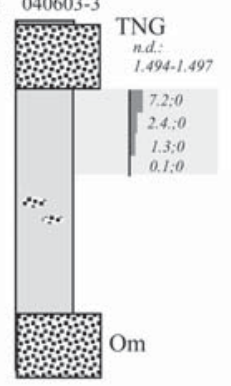

18

[Jogan eruption

AD864]

Nagaoyama E flank

[貞観864]

長尾山東 Nagaoyama

040603-2 / scoria

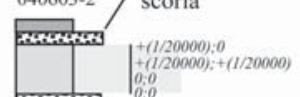

\%

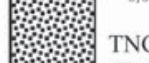

TNG

(Tenjin scoria)
19

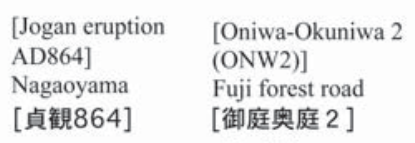

[御庭奥庭 2] $\begin{array}{lll}\text { 長尾山山頂 } & \text { 富士林道 } & \text { n.d: } \\ 041106 & 041104-3 & \text { 1.494-1.497 }\end{array}$
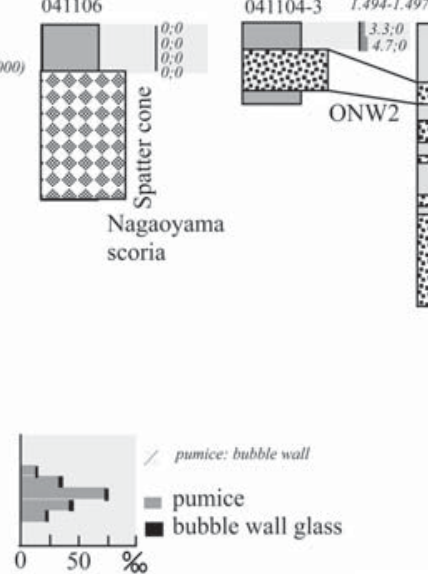
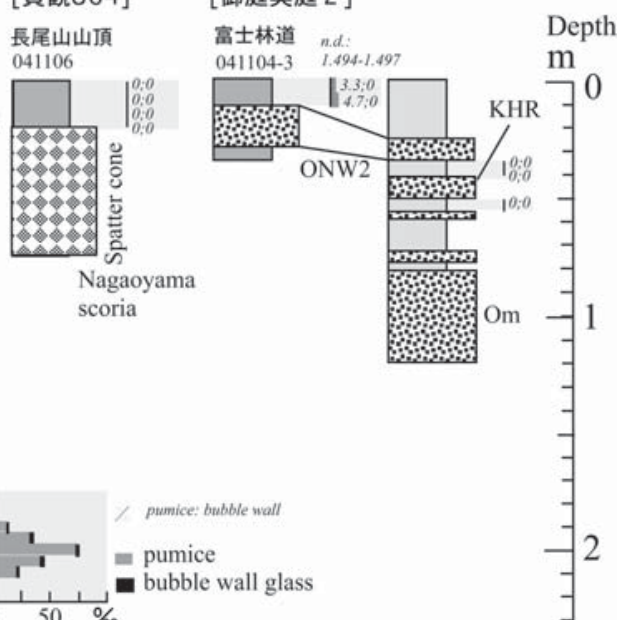

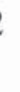

Fig. 4 Columnar sections of trench sites and outcrops on the E to N flank of Fuji Volcano.

correlated. In this paper, these are called as the Scoria layers 1 to 8 ( $\mathrm{Scl}$ to 8 ), beginning from the top. The characteristics of each scoria layer are as follows. The symbols within parentheses are the same as those used by Uesugi (2003). The Scoria layer 5, 6, and 7 were newly defined (Figures 2 and 4).

The Scoria layer 1 (S-24-10): It is brick red in color and is composed of weathered clay-rich scoria, and this layer is distributed only on the east side of Fuji Volcano.

The Scoria layer 2 (S-24-9): It has moderate vesicularity and forms millet-sized bubbles. It contains redbrown volcanic bombs. This layer is distributed only in the Subashiri area at the fifth stage.

The Scoria layer 3 (S-24-7): It has high vesicularity and has a very spiky form. This layer is distributed in the northern part of Subashiri at the fifth stage.

The Scoria layer 4 (S-24-6): It has low vesicularity and contains altered rock fragments. This layer is distributed only on the west side of Fuji Volcano.

The Scoria layer 5 (newly defined; S-24-5-3): It has moderate vesicularity and forms millet-sized air bubbles. It is distributed only on the west side of Fuji Volcano.

The Scoria layer 6 (newly defined; S-24-5-2): It has high vesicularity and has a very spiky form. It also has a lustrous bubble surface.

The Scoria layer 7 (newly defined; S-24-5-1): It has mild/low vesicularity. It borders the Scoria layerria layerayererr 880 sandy weathering volcanic ash. It is distributed only on the west side of Fuji Volcano. 
The Scoria layer 8 (S-24-5): This has low vesicularity and contains volcanic bombs. It accompanies lahar deposits having thicknesses of several tens of meters in the area to the northwest of Fuji Volcano. It is distributed from the west to the northwest flank.

In Dainichido East (051127-2), the Scoria layers 1, 4, 5, 6, and 8 are found below Ho (Figures 2, 4, and 6). The horizon of the volcanic glasses originating in the Kozushima-Tenjosan tephra exists in this area; this is based on the fact that the maximum value ( $49.7 \%$ ) of the content ratio of volcanic glasses with low refractive index was recorded at the level between the Scoria layer 4 and the Scoria layer 5.

In Kyu-Umagaeshi northeast (051127-1), the Scoria layers 1, 3, 4, 5, 6, and 8 are found below Ho (Figures 2, 4 , and 7 ). The maximum value ( $36 \%$ ) of the content ratio of volcanic glasses with low refractive index was recorded at the level between the Scoria layer 4 and the Scoria layer 5 .

The outcrop location on the downside of the Subashiri fifth stage (041104-1) was reported in the Geographical guide book of Fuji Volcano (P91-94) (Uesugi, 2003) (Figures 2, 4, and 8). In this study, a small amount of volcanic glasses was detected in the level immediately below Ho and the level below the Scoria layer 3 and 4 . The volcanic glasses detected in the level immediately below Ho are the bubble-wall-type and their refractive index is more than 1.520. The tephra comprising volcanic glasses might be the Asama B tephra (pumice-type volcanic glasses: 1.524-1.532; Machida and Arai, 2003), which originated from the Asama eruption in AD 1,108 and the tephra which erupted from Fuji Volcano during the last 3,000 years (upper tephra group of Younger Fuji Volcano; pumice-type volcanic glasses: 1.518-1.538; Machida and Arai, 2003). However it is difficult to correlate with these tephras because the volcanic glasses detected at the outcrop are of the bubble-wall-type. In general, the volcanic glasses originating in basaltic deposits have a high refractive index. It is reasonable to consider that the volcanic glasses with high refractive index detected at the outcrop are of the secondary deposits origin from Fuji Volcano.

The Subashiri fifth stage (040604-2) is the outcrop along a bulldozer road located above the parking are a at the Subashiri fifth stage (Figures 2,4). Among the weathered volcanic ash soil layers intercalated with the tephra layers below Ho, a small amount of volcanic glasses were detected in the level just above the Scoria layer 3 and the level just below the Scoria layer 4 . We could not determine the source of the tephra because the refractive index of the volcanic glasses detected in the level immediately above the Scoria layer 3 could not be measured due to its extremely small size. However, it is unlikely that this scoria is the Kozushima-Tenjosan tephra because the volcanic glasses have a bubble-wall-type structure. With regard to the pumice-type volcanic glasses and bubble-walltype glasses detected in the level below the Scoria layer 4 , the refractive indices are 1.498-1.500 and greater than 1.520 , respectively.

The trail at the Subashiri fifth stage (041104-2) is the outcrop that is located along the road to enter the trail up the mountain from a teahouse at Subashiriguchi. The Scoria layers 1, 2, 3, 4, 6, and 8 are found below Ho. The volcanic glasses originating in the widespread tephra were not detected in the weathered volcanic ash soil intercalated with the tephras (Figures 2, 4).

The Gotenba lava flow proposed by Tsuya (1968) comprises several lava flows (Uesugi, 2003). In this study, these lava flows are called as the Suabshiri lava flow group (Sub).

At the no. 2 outcrop along the Yamanaka forest road (051128-2), the Scoria layers 3 and 5, and the secondary deposit of the Scoria layer 8 are found (Figures 2, 4 , and 9$)$. The maximum value $(37.7 \%$ ) of the content rate of the volcanic glasses with low refractive index was obtained in the level between the Scoria layer 3 and the Scoria layer 5. It is considered to be the Kozushima-Tenjosan tephra horizon.

At the no. 1 outcrop along the Yamanaka forest road (051128-1), the Subashiri lava flow (Sub) and the Scoria layers 5, 6, 7, and 8 are found (Figures 2, 4, and 10). The upper part of the Scoria layer 8 is a lahar deposit. In the level below Sub, the maximum value (53.3\%) of the content rate of pumice-type glasses or low-vesicularity glasses, which have a low refractive index was measured. The microstructure and the refractive index of the volcanic glasses, the geology of the surrounding area, and the study results indicate that these volcanic glasses originate in the Kozushima-Tenjosan tephra. It is considered that the ash-fall horizon of the KozushimaTenjosan tephra lies between Sub and the Scoria layer 5.

At the no. 3 outcrop along the Yamanaka forest road, Sub and the Scoria layers 6 and 7 are found in the descending order. The maximum value $(16.7 \%)$ of the content ratio of low-refractive index glasses, which are either of the pumice-type or low-vesicularity glasses, was recorded at the level immediately above the Scoria layer 6 . The microstructure and the refractive index of the volcanic glasses and the geology of the surrounding area, indicate that these volcanic glasses originate in the Kozushima-Tenjosan tephra.

At the no. 4 outcrop along the Yamanaka forest road (051128-3), Sub the Scoria layer 6 and 7, the lahar deposit, and the Scoria layer 8 are found in the descending order (Figures 2 and 4$)$. The maximum value $(0.7 \%$ ) of the content ratio of low refractive index glasses, which are either of the pumice-type or low-vesicularity glasses, was recorded at the level immediately above the Scoria layer 6. The microstructure and the refractive index of the volcanic glasses and the geology of the surrounding area indicate that despite the low con- 
tent ratio, it could be concluded that these volcanic glasses originate in the Kozushima-Tenjosan tephra.

Along the Kofuji forest road (041105-02), volcanic glasses having low vesicularity were detected in the weathered volcanic ash soil above the Scoria layer 8 (Figures 2 and 4). Furthermore, the detected low-vesicularity volcanic glasses have a refractive index in the range of 1.494-1.498. The microstructure and the refractive index of the volcanic glasses, the geology of the surrounding area, and the study results indicate that these volcanic glasses originate in the Kozushima-Tenjosan tephra. Since the volcanic glasses from the Kozushima-Tenjosan tephra can be found only in the level above the Scoria layer 8, the horizon of the Kozushima-Tenjosan tephra lies above the Scoria layer 8 .

\subsection{On the north to northwest flank of Fuji Volcano}

\section{Correlation between the Hinokimarubi 2 lava flow (Hnm 2) and the Takamarubi lava flow (Tam)}

Along the transportation road (051128-5), volcanic glasses with low refractive index were detected in the level between the Takamarubi lava flow (Tam; Tsuya, 1968) and the scoria layer (Figures 2 and 4). The microstructure and the refractive index of the volcanic glasses and the geology of the surrounding area indicate that these volcanic glasses originate in the Kozushima-Tenjosan tephra.

In Kaneyama (040604-1), the volcanic glasses were detected in the soil that covers the Hinokimarubi 2 lava flow (Hnm 2; Tsuya, 1968) (Figures 2 and 4). The content ratio of the volcanic glasses increases as the level moves downward, and the maximum value (20.3\%) was measured at a level immediately above Hnm 2. The detected glasses are mainly of the pumice-type and low-vesicularity-type, and their refractive index is in the range 1.494-1.497. The microstructure and the refractive index of the volcanic glasses and the geology of the surrounding area indicate that these volcanic glasses originate in the Kozushima-Tenjosan tephra. It is assumed that the ash-fall horizon of the Kozushima Tenjosan tephra exists at the same level or immediately above Hnm 2.

A trench excavation survey (GS-FJ-55) was conducted in Oshino Vil. on the northern flank of Fuji Volcano (Nakano et al., 2007) (Figures 2 and 4). The Takamarubi lava flow (Tam), the unknown scoria layers. etc. are found in the descending order. The volcanic glasses with low refractive index were not detected in the weathered volcanic ash soil between each scoria.

If Hnm 2 and Tam are identical, both lava flows could be considered to be covered by the KozushimaTenjosan tephra.

\section{Correlation with the Kenmarubi 2 lava flow (Ken 2)}

At Fukuzawabashi (040603-5), to the east of the Yamanashi Institute of Environmental Sciences, the presence of volcanic glasses was confirmed (the Geographical guide book of Fuji Volcano (P38-42) (Uesugi, 2003)) (Figures 2, 4, and 11). In this study, volcanic glasses were detected in the weathered volcanic ash soil immediately below the Kenmarubi 2 lava flow (Ken 2) and a scoria layer whose origin is unknown (Figure 11). Uesugi (2003) described that this scoria could be similar to the Tenjin touge scoria. The maximum content rate $(26.0 \%)$ of volcanic glasses was recorded at the level immediately below Ken 2 . The detected glasses mainly comprise pumice-type and lowvesicularity glasses. Furthermore, their refractive index lies in the narrow range of 1.495-1.498. The microstructure and the refractive index of the volcanic glasses and the geology of the surrounding area indicate that these volcanic glasses originate in the Kozushima-Tenjosan tephra. The ash-fall horizon of this tephra would lie in the level between Ken 2 and the scoria layer.

\section{Correlation with the Jogan eruptive deposits}

At the Narusawa quarry (041104-5), volcanic glasses were detected in the level between the Aokigahara lava flow (Tsuya, 1968) and the Omuro scoria (Om) (Figures 2, 4, and 12). The maximum content ratio (19.0 $\%$ ) was measured immediately below the Aokigahara lava flow. The detected glasses mainly comprise pumice-type and low-vesicularity glasses. Furthermore, their refractive index lies in the range of 1.494-1.498. The microstructure and the refractive index of the volcanic glasses and the geology of the surrounding area indicate that these volcanic glasses originate in the Kozushima-Tenjosan tephra. The Aokigahara lava flow erupted after the Kozushima-Tenjosan tephra fall.

At the Nagaoyama east flank (040603-2), extremely small amounts of the bubble-wall-type and pumice-type volcanic glasses are detected in the level between the Nagaoyama scoria and the Tenjinyama scoria (Koyama, 1998)(Figures 2 and 4). The content ratio of the volcanic glass was too low and the volcanic glasses were too small to measure the refractive index. It is likely that the layer is not the widespread tephra because the distributed patterns of the volcanic glasses are scattered.

At the trench in the vicinity of the Nagaoyama triangulation point (041106), the volcanic glasses that originated from the widespread tephra were not detected in the soil covering the Nagaoyama scoria (Figures 2 and 4). It is reasonable to consider that the Nagaoyama scoria erupted after the Kozushima-Tenjosan tephra. 
Obuchimarubi lava

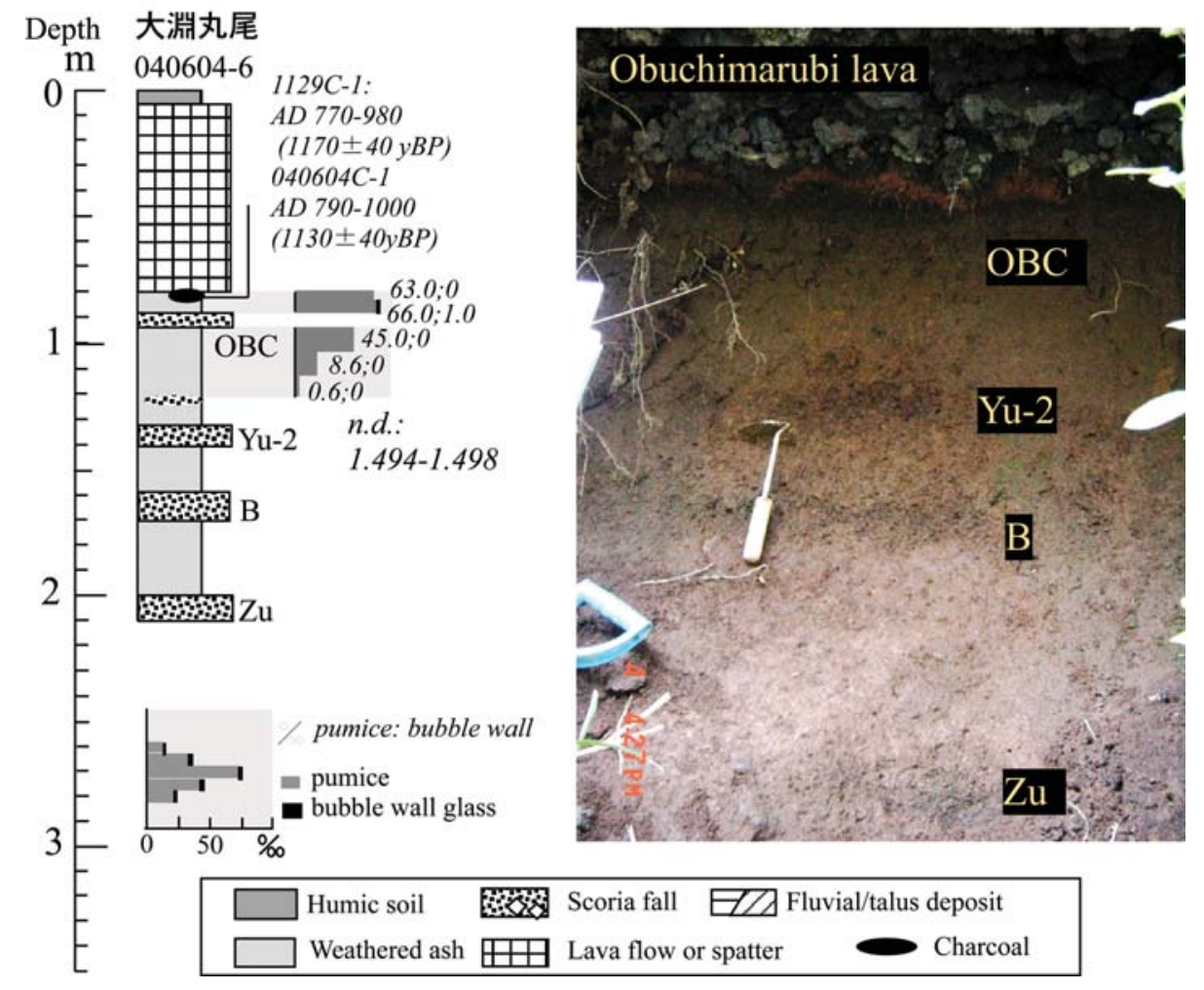

Fig. 5 Columnar section and photograph of the outcrop of Obuchimarubi lava flow.

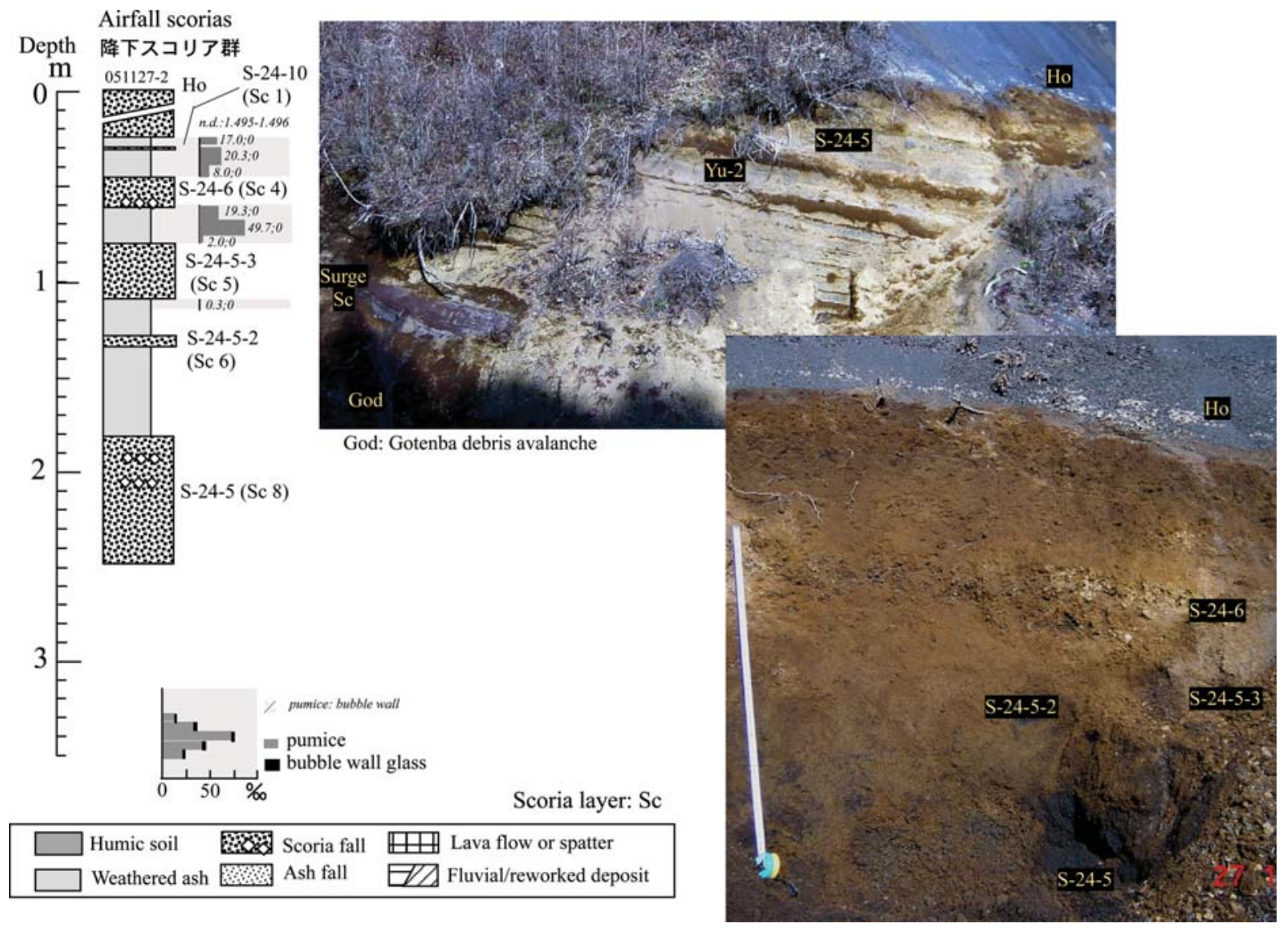

Fig. 6 Columnar section and photograph of the outcrop at Dainichido. 


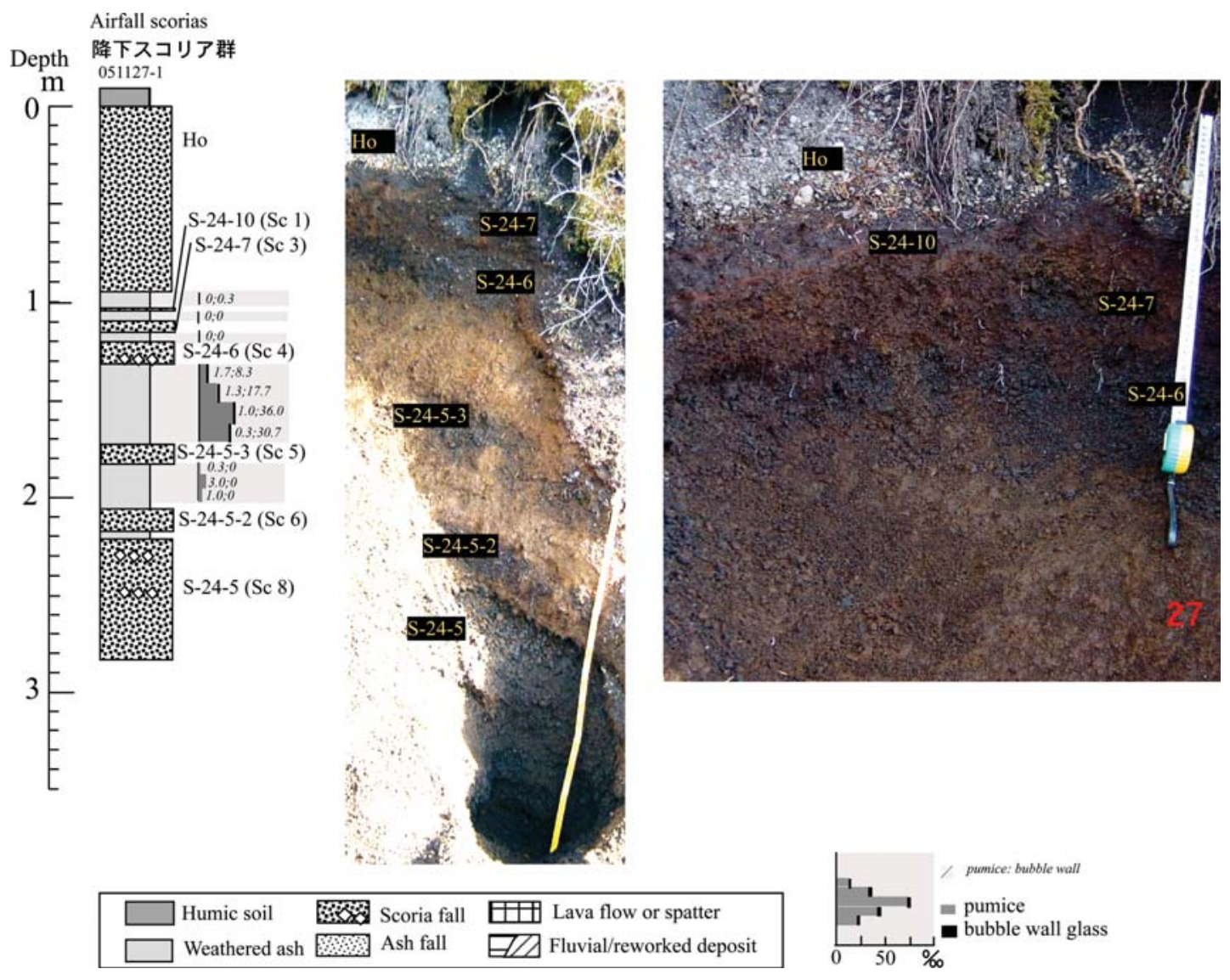

Fig. 7 Columnar section and photograph of the outcrop NE of Umagaeshi.

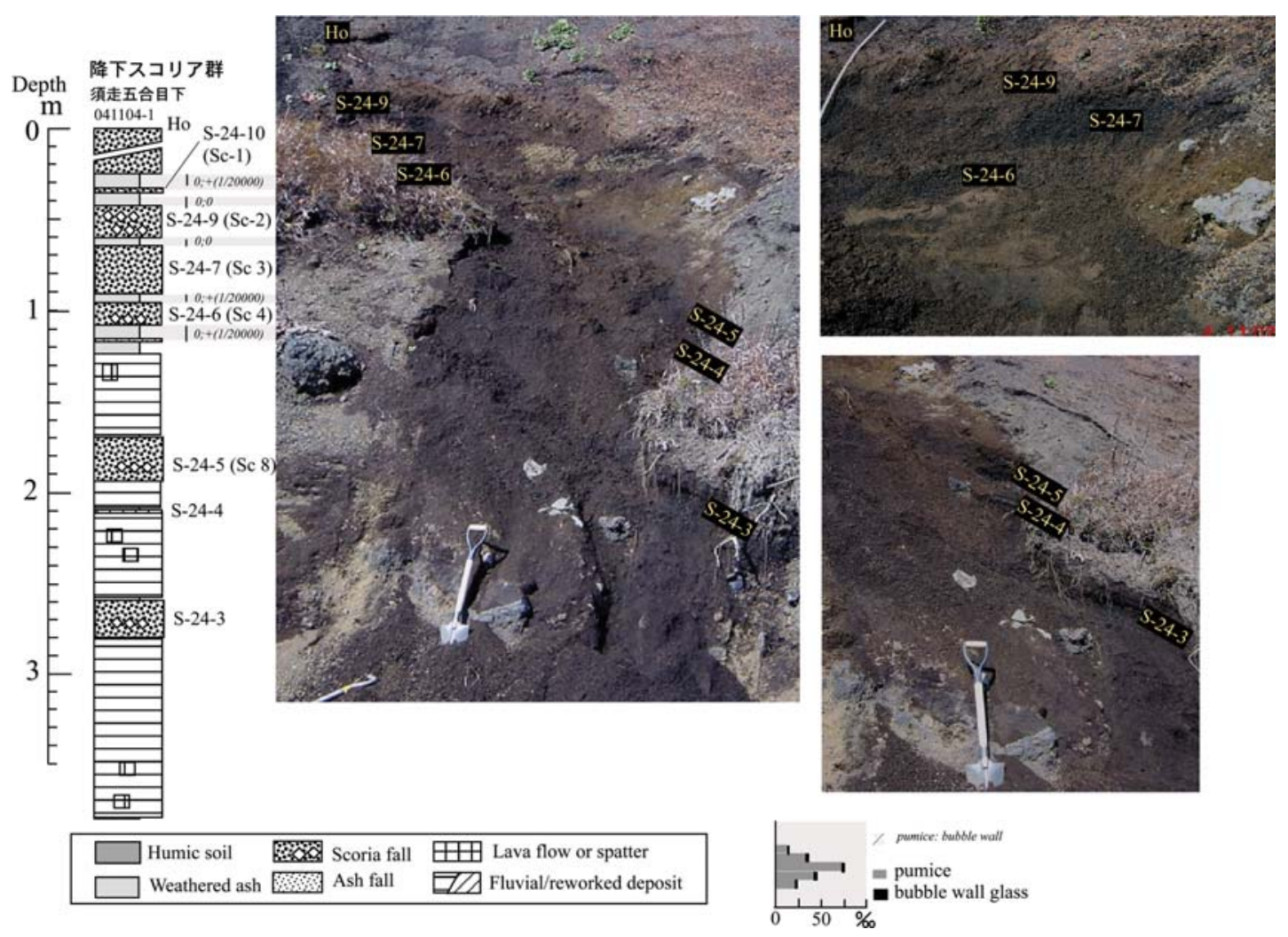

Fig. 8 Columnar section and photograph of the outcrop at the at the Subashiri fifth stage. 


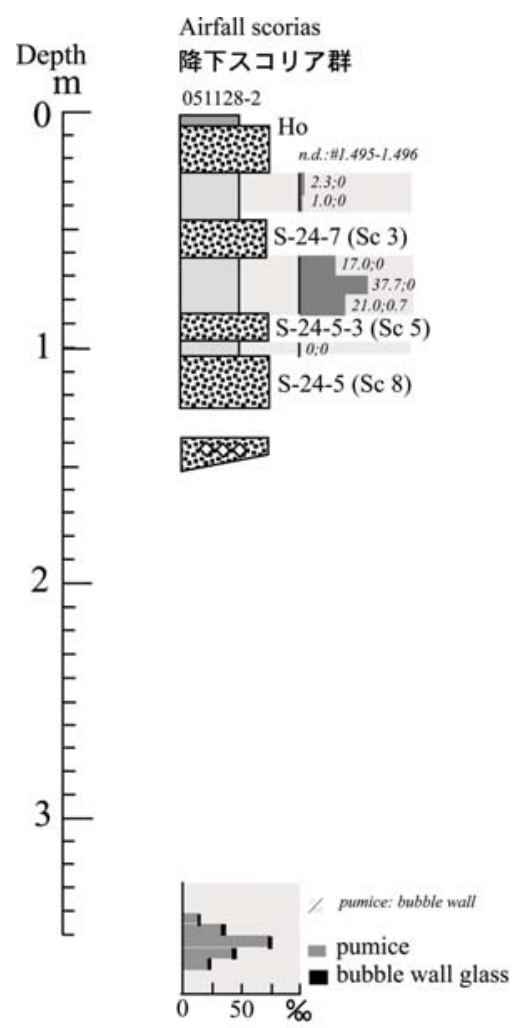

Humic soil Scoria fall $\mathrm{M}$ Lava flow or spatte Weathered ash W. Ash fall EV Fluvial/reworked deposit

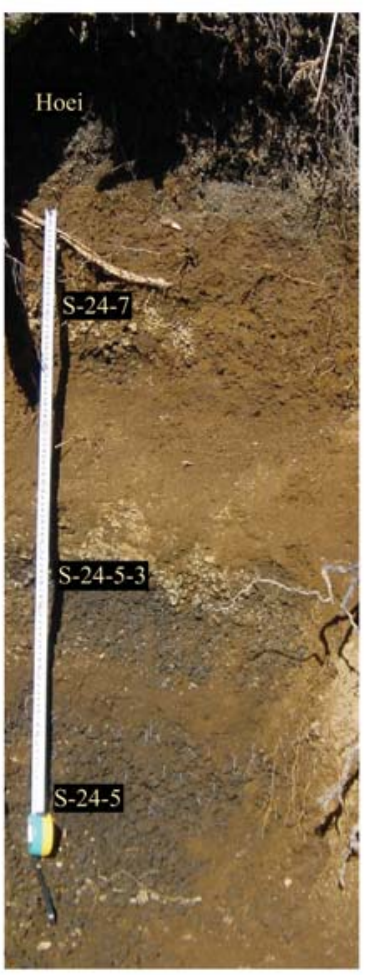

Fig. 9 Columnar section and photograph of the no.2 outcrop along the Yamanaka forest road.
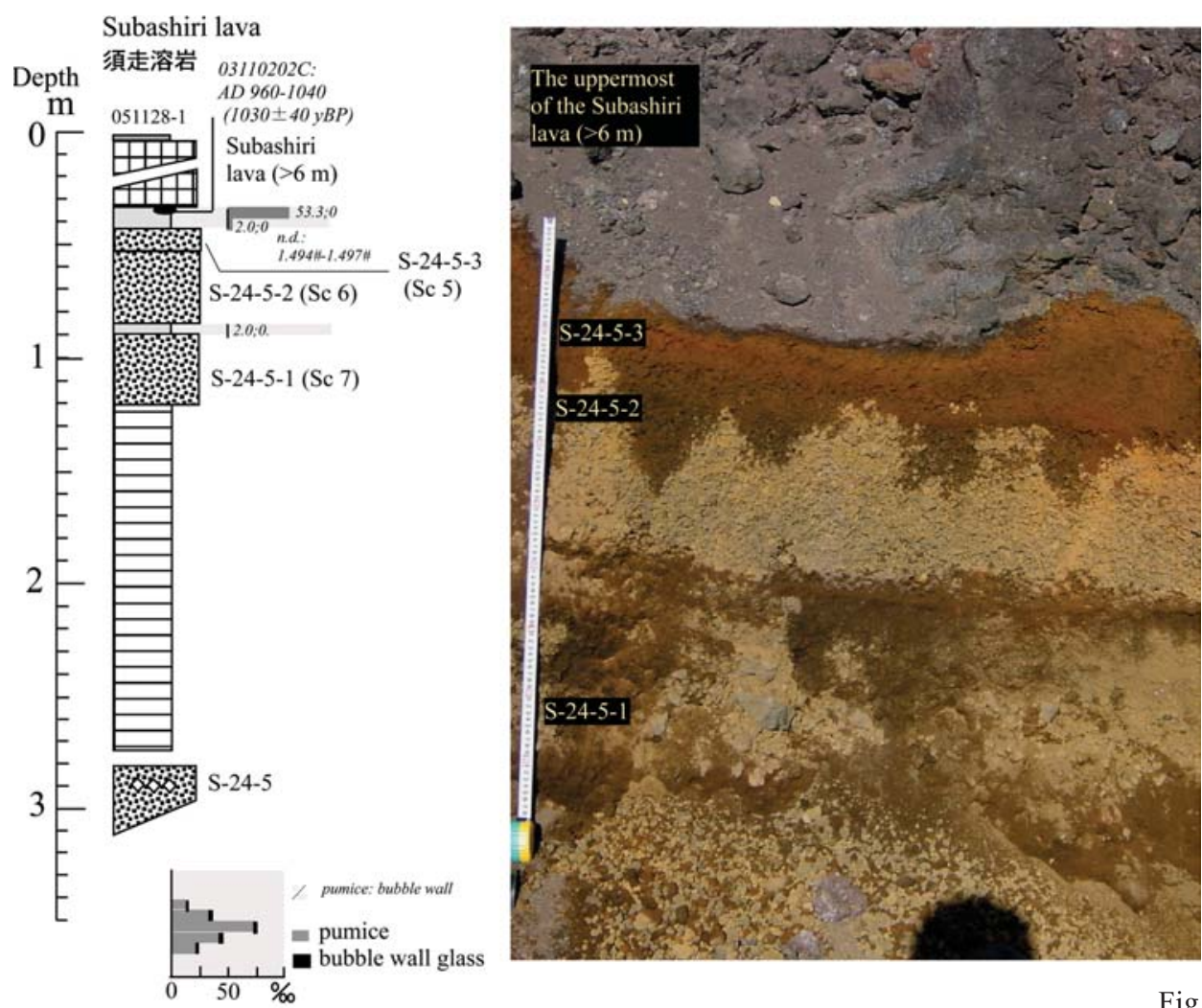

Humic soil ED Fluvial/reworked deposit
Fig. 10 Columnar section and photograph of the no.1 outcrop along the Yamanaka forest road. 


\section{The Tenjin-Igatono eruptive deposits}

At the southeast Igatonoyama (040603-3), volcanic glasses are detected in the weathered volcanic ash soil below the scoria (TNG) associated with the TenjinIgatono lava flows (Tsuya, 1968) (Figures 2 and 4). The content ratio of the glasses increases as the level moved upward. The maximum value $(7.2 \%)$ was recorded immediately below TNG. The refractive index of the volcanic glasses was in the range of 1.494-1.497. The microstructure and the refractive index of the volcanic glasses and the geology of the surrounding area indicate that these volcanic glasses originate in the Kozushima-Tenjosan tephra. The content ratio of the volcanic glasses increases as the level moves upward through TNG. This results show that the ash-fall horizon of the Kozushima-Tenjosan tephra is in or immediately below TNG.

\section{Correlation with the Kita-Tenjin vent}

According to the geological survey based on the red relief image map conducted by Asia Air Survey Co., Ltd., the spatter group was confirmed along the direction N30W from the point at latitude 35.26.58 north and at longitude 138.40 .46 east (Suzuki and Chiba's private statement). In this study (041105-1), the volcanic glasses with a bubble-wall structure and low vesicularity were detected in the soil covering this spatter group (Figures 2 and 4). The maximum content rate of the volcanic glasses was $0.6 \%$ and the refractive index lies in the broad range of 1.497-1.505. The microstructure and the refractive index of the volcanic glasses and the geology of the surrounding area indicate that these glasses are a mixture of the volcanic glasses from the KozushimaTenjosan tephra, the Kawagodaira tephra, and KikaiAkahoya tephra (K-Ah; Machida and Arai, 2003). This result could not provide direct evidence that the location of this spatter group corresponded with the extent of the Tenjin-Igatono eruptive vent.

\section{Correlation with the Oniwa-Okuniwa 2 eruptive deposit}

Along the Fuji forest road in north Usuyama (0411043 ), volcanic glasses were detected in the soil that covers the scoria associated with the eruption of the OniwaOkuniwa 2 lava flow (Onw 2; Tsuya, 1968) (Figures $2,4$, and 13$)$. The maximum content rate $(4.7 \%$ ) was recorded at the level immediately above the OniwaOkuniwa eruptive deposit (ONW2). The detected glasses mainly comprise pumice-type and low-vesicularity glasses. The refractive index was in the range of 1.494-1.497. The microstructure and the refractive index of the volcanic glasses, and the geology of the surrounding area indicate that these volcanic glasses originate in the Kozushima-Tenjosan tephra. The volcanic glasses that originate in the Kozushima-Tenjosan tephra exhibit the maximum value at the area immediately above ONW2. The ash-fall horizon of the Kozushima-Tenjosan tephra is considered to be at, in, or immediately above ONW2. Meanwhile, the volcanic deposits that originate in widespread tephra were not detected in the weathered volcanic ash soil between ONW2 and the Kouriike eruptive deposit (KHR) and the level below KHR.

\section{Discussion}

\subsection{Stratigraphy based on calendar age and horizon of the Kozushima-Tenjosan tephra}

Figure 14 shows the stratigraphical correlation with the Kozushima-Tenjosan tephra and the eruptive events in Fuji Volcano based on the results of the field survey and volcanic ash analysis. The eruptive deposits that are considered to be older than the KozushimaTenjosan tephra are as follows: the Oniwa-Okuniwa eruptive deposit (ONW2); the Takamarubi lava flow (Tam); the Scoria layers 5, 6, 7, and 8 (in this study); the Nishi-Futatsuzuka scoria (NFT); the Obuchi scoria (OBC); and the Kansuyama scoria (KNS). On the other hand, the eruptive events that are considered to be younger than the Kozushima-Tenjosan tephra are as follows: the Jogan eruption (the Nagaoyama scoria and the Aokigahara lava flow); the Tenjin-Igatono eruptive deposit (TNG); the Kenmarubi 2 lava flow (Ken 2); the Mizugatsuka-hinokimarubi lava flow (Him); the Higashi-Usuzuka south lava flow (Hum); the Fudosawa lava flow (Fud); the Obuchimarubi lava flow (Obu); the Scoria layers 1, 2, 3, and 4; and the Subashiri lava flow. Subashiri lava flow is defined as the eruptive deposit (Subashiri lava flow I) located at the top among the series of the Subashiri lava flows (Subashiri lava flows0I-III; Uesugi, 2003). The AMS age around Cal AD 1,000 was obtained based on the carbonized wood located immediately below the lava flow (Yamamoto et al., 2005; Takada et al., 2007).

The results of carbon dating were not sufficient to determine whether these volcanic deposits were produced before AD 838 (Yamamoto et al., 2005; Takada et al., 2007), except for the Jogan eruption (AD 864866), whose eruption age is recorded in ancient literatures, and Fud, Ken 2, and the Subashiri lava flow, which were determined to have originated after AD 838 based on the carbon dating results that have a 2 sigma error. This study provides a reliable time axis in the period when the volcanoes were fairly active (Yamamoto et. al., 2005; Takada et al., 2007). By using this time axis, it is possible to determine that it was around AD 850950 when the direction of the fissure eruption shifted from the NW-SE to the N-S. 


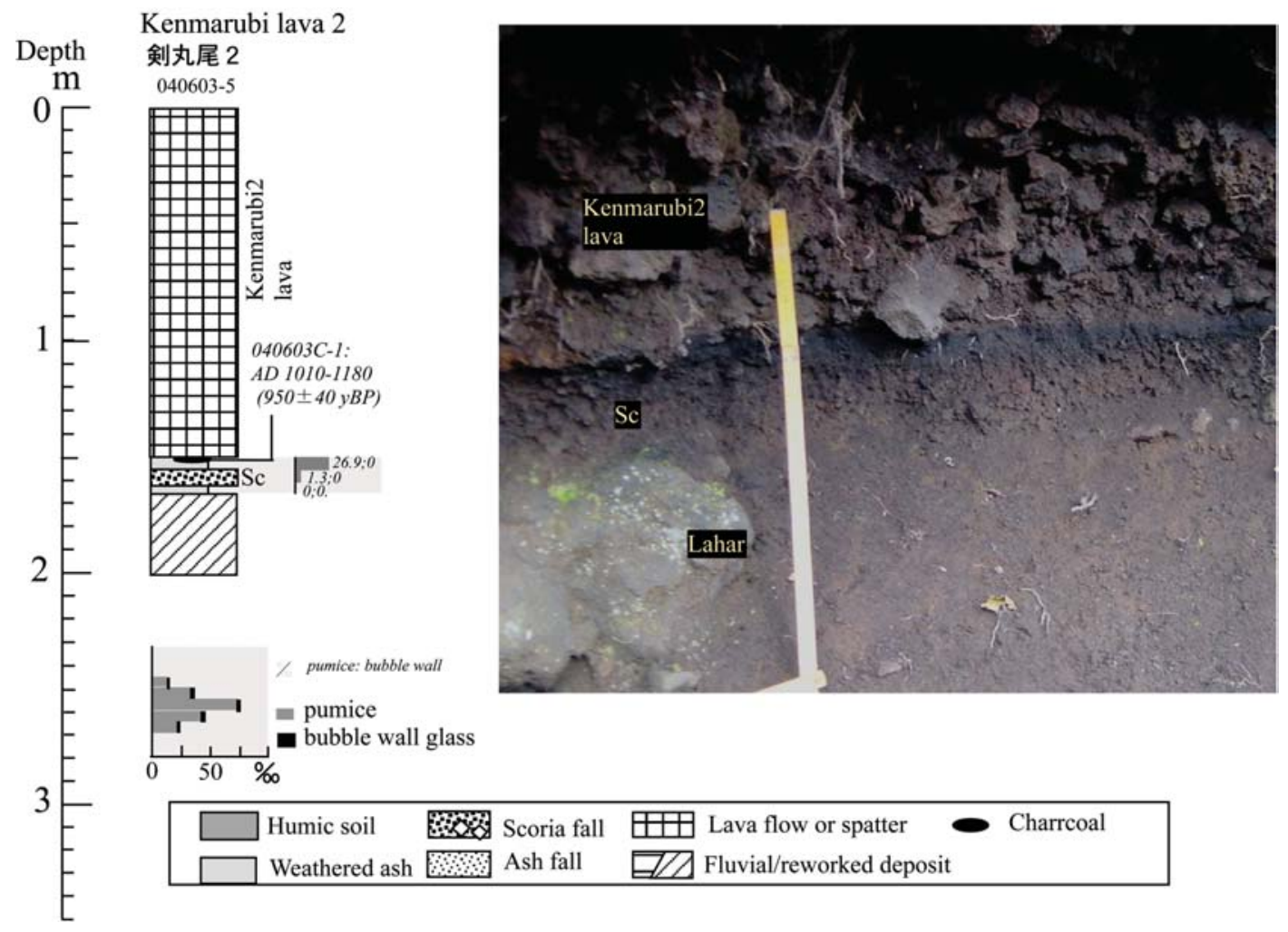

Fig. 11 Columnar section and photograph of the outcrop of Fukuzawabashi.

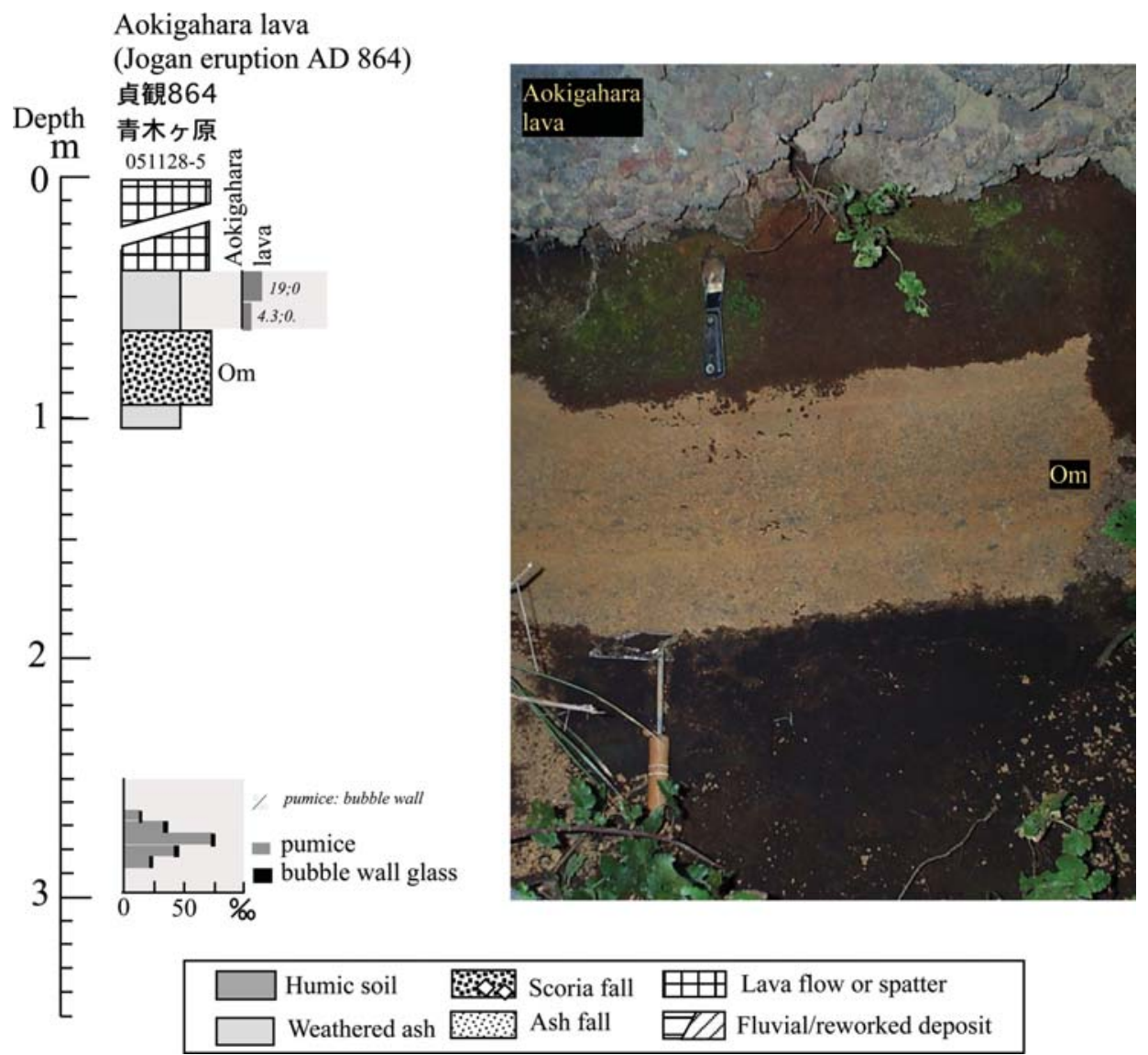

Fig. 12 Columnar section and photograph of the Narusawa quarry site ruins. 


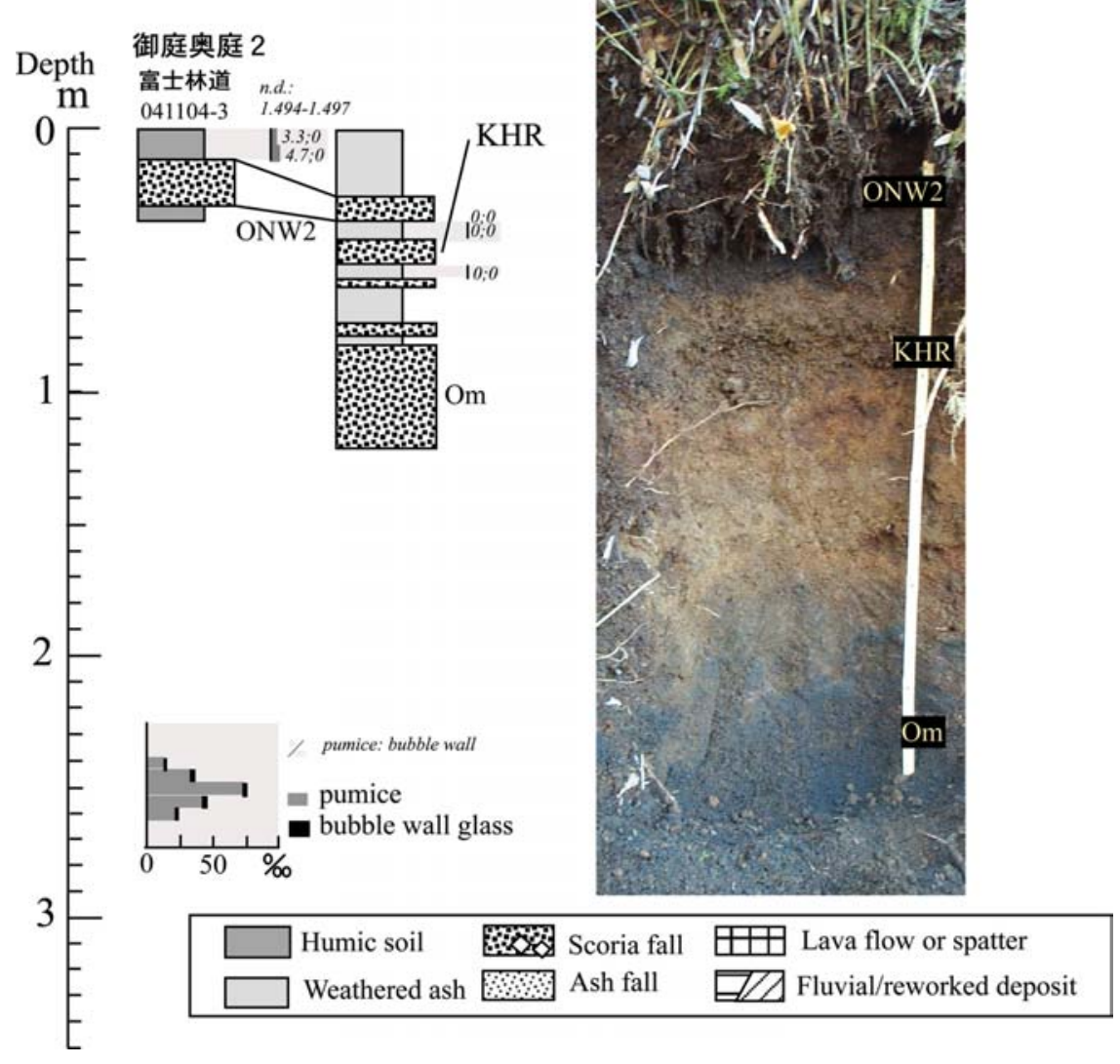

Fig. 13 Columnar section and photograph of the outcrop $\mathrm{N}$ of Usuyama.

scoria falls at the eastern flank of Fuji and tentatively designated them as the Scoria layers 1 to 8 in the descending order. Hereafter, the correlation with the known tephra in previous studies is attempted for these eight falls.

First, we would like to point out incorrect readings in previous studies. Koyama (1998) and Uesugi (2003) argued that the Subashiriguchi scoria a ( $\mathrm{Sb}-\mathrm{a})$ and $b(\mathrm{Sb}-\mathrm{b})$ are distributed near the horizon of the KozushimaTenjosan tephra in the eastern to northeastern sector of the volcano. However, our investigation concludes that the ages of $\mathrm{Sb}-\mathrm{a}$ and $\mathrm{Sb}-\mathrm{b}$ are fairly different from those of the Kozushima-Tenjosan tephra. The poorly vesiculated scoria found along the Kofuji forest road (041105) that was identified as $\mathrm{Sb}$-a originated from the fissure of western KoFuji according to Koyama, 1998. However, it has been verified to be lower than the horizon of the

\subsection{The age of Tenjin-Igatono eruptive deposit}

Koyama (1998) considered that the age of the eruption that produced the Tenjin-Igatono eruptive deposit corresponds to the Enryaku eruption (AD 800-802), based on the description of historical literatures and the comparison of the stratigraphical succession of the Nagaoyama scoria (Jogan eruption; AD 864-866). However, this study revealed that the horizon of the TenjinIgatono eruption is upper than that of the KozushimaTenjosan tephra. Thus far, there is no description of the eruptions during the period between AD 838 and the Jogan eruption in reliable historical literatures (Koyama, 1998). Therefore, further studies are required to determine the age of the eruption. Since the lower limit of the Tenjin-Igatono eruption is after AD 838, the interval between the Tenjin-Itogano and Jogan eruptions is less than 26 years. This short period is consistent only with the presence of 1-2 cm thick weathered volcanic ash soil layers between the eruption products. The present highly active volcanoes such as Izu-Oshima, Miyakejima, and Usu exhibit eruption intervals of 2030 years. The activity of Fuji Volcano in the past corresponds to the current activity of such volcanoes.

\subsection{Review of tephra stratigraphy at eastern flank of Fuji Volcano}

As mentioned in section 4.2, we found a new set of
Kozushima-Tenjyozan tephra, and is designated as the Scoria layer 8 in this study. The poorly vesiculated scoria fall (identified as Sb-a or S-24-9 by Uesugi, 2003) and the vesiculated scoria fall (identified as Sbb or S-24-7 by Uesugi, 2003) that are overlaid by the Hoei tephra are confirmed to be older than the Kozushima-Tenjosan and are designated as the Scoria layers 2 and 3 in this study.

Second, the correlation to the tephras found in previous studies is attempted. The Scoria layers 1 to 4 are younger than the Kozushima-Tenjosan tephra. The Scoria layer 1 is identical to S-24-10 of Uesugi (2003). The Scoria layer 2 is a newly discovered fall that contains bombs, and its distribution is restricted near the Subashiri fifth stage. The occurrence of the bombs and the distribution indicates that the source vent is located near the Subashiri fifth stage. The Scoria layer 3 is the same as S-24-7 of Uesugi (2003), and its horizon is the same as that of the Subashiri lava. This observation indicates that the scoria fall originates from the fissure that issued the lava. The Scoria layer 4 is identical to S-24-6 of Uesugi (2003) and the calibrated age is AD 790-1,000 (2 sigma; Yamamoto et al., 2005).

The Scoria layers 5 to 8 are older than KozushimaTenjosan. The Scoria layer 5 is considered to have issued from the fissure of the Hinokimarubi 2 and the Takamarubi lava flows (Hnm 2 / Tam). The volcanic 

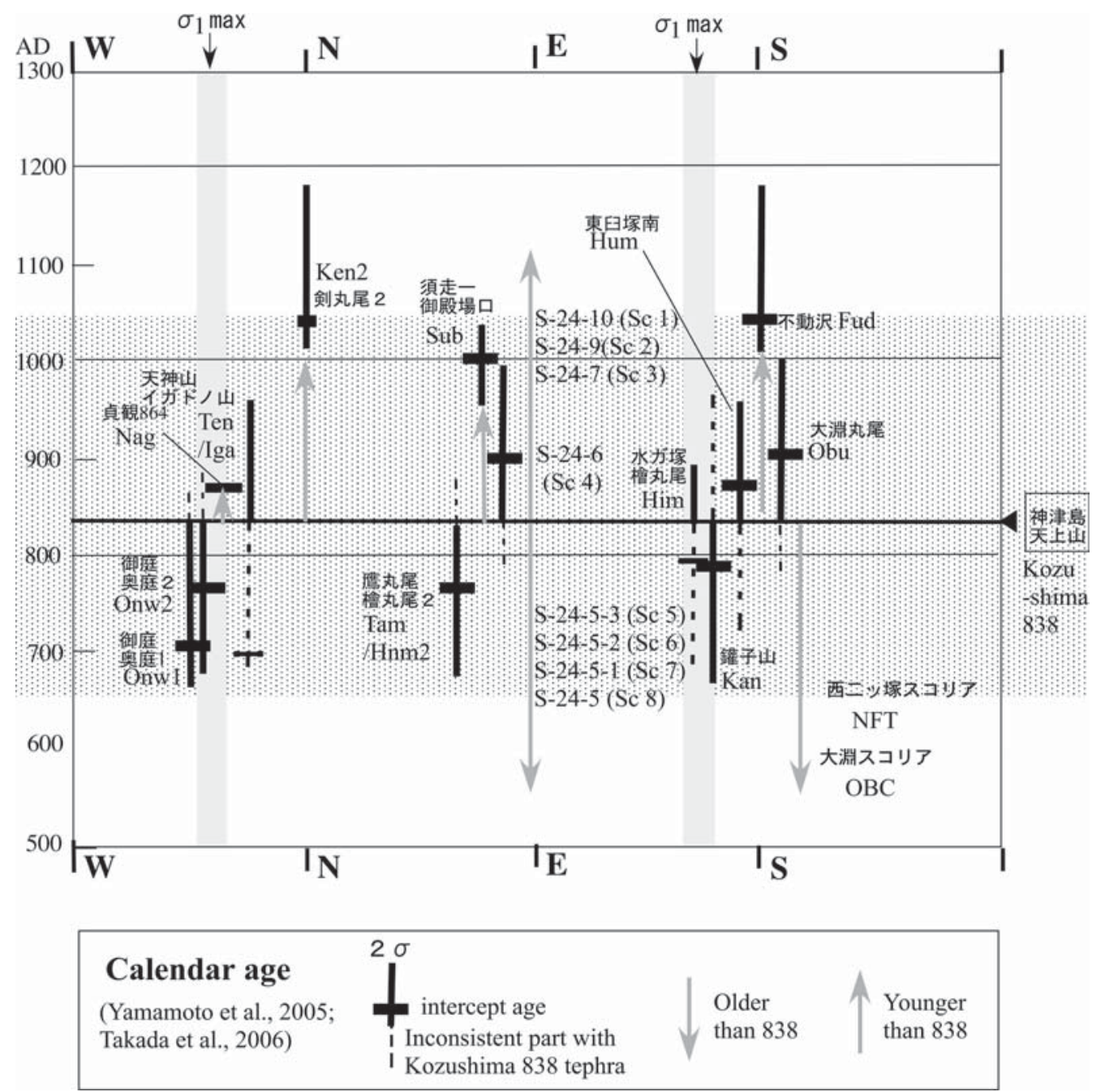

Fig. 14 Summary of stratigraphy of AD 700-1,000 of Fuji Volcano. ${ }^{14} \mathrm{C}$ ages are from Yamamoto et al. (2005), and Takada et al. (2007).

glass of the Kozushima-Tenjosan tephra densely appears in the soil just above the Hinokimarubi 2 lava flows. The calibrated carbon age of the soil just below Tam was found to be AD 765 (AD 670-875; 2 sigma). Therefore, these lava flows are presumed to be the products of the Enryaku eruption (AD 800-802).

Our study revealed that the tephra stratigraphy of Koyama (1998) in the eastern to north-eastern flank of the volcano is inaccurate due to the misunderstanding of the layer that is identified as the Scoria layer 8 in this study. Koyama (1998) considered that Sb-b is the product of the Enryaku eruption that issued from a fissure of western Kofuji. As mentioned before, the Scoria layer 8 was incorrectly identified by Koyama as Sb-b. Therefore, Sb-b is not a product of the Enryaku eruption. Furthermore, the source of the Scoria layer 8 is not to the west of Kofuji. Our investigation revealed that the source of the Scoria layer 8 is much wider, i.e., the scoria identified as the Yufune scoria 2 at Subashiri fifth stage by Koyama (1998) corresponds to the Scoria layer 8 in this study. We found a thick (up to $3 \mathrm{~m}$ ) layer of the
Scoria layer 8 that contains bombs along a NEE trending line that was $3 \mathrm{~km}$ long. This line would be the source fissure of the Scoria layer 8.

\section{Summary}

(1) The volcanic glasses with low refractive index, which are distributed around Fuji Volcano, consist of single fall units. Toward the south, the layer thickens and the particle diameter increases. And on the basis the results of the vesicularity analysis, the microstructure, discussion of the historical literatures, and chemical analysis of the glasses are considered to originate in the Kuzushima-Tenjosan tephra (AD838).

(2) The Kozushima-Tenjosan tephra is a key to establish the stratigraphy of the tephras of active stages of Fuji Volcano.

(3) The eruptive deposits determined to be older than the Kozushima-Tenjosan tephra are the Oniwa-Okuniwa 2 (ONW 2), the Takamarubi-Hinokimarubi 2 lava flow (Tam / Hnm 2), the Nishi-Futatsuzuka scoria (NFT), 
the Obuchi scoria (OBC), and the Kansuyama scoria (KNS). Meanwhile, the eruptive deposits of the TenjinIgatono eruptive deposit (TNG), the Jogan eruptive deposit (the Aokigahara lava flow and the Nagaoyama scoria), the Kenmarubi 2 lava flow (Ken 2), the Mizugatsukahinokimarubi lava flow (Him), the Higashi-Usuzuka Minami lava flow (Hum), the Fudosawa lava flow (Fud), the Obuchimarubi lava flow (Obu), and the uppermost of the Subashiri lava flows are confirmed to be younger than the Kozushima-Tenjosan tephra.

(4) The stratigraphy of the eastern flank of Fuji Volcano in the descending order is as follows: the Hoei tephra, the Scoria layer 1 (S-24-10), the Scoria layer 2 (S-24-9), the Scoria layer 3 (S-24-7), the Scoria layer 4 (S-24-6), the Kozushima-Tenjosan tephra, the Scoria layer 5 (newly defined; S-24-5-3), the Scoria layer 6 (newly defined; S-24-5-2), the Scoria layer 7(newly defined; S-24-5-1), and the Scoria layer 8 (S-24-5).

Acknowledgements: We thank Y. Ishizuka of AIST, Y. Suzuki and T. Chiba of Asia Air Survey Co., Ltd., for their help in our excavation surveys and their advice. We also thank Y. Yamamoto for his excavation of our trench. In our project, we used the KozushimaTenjosan and the Niijima-Mukaiyama tephras in Miyakejima and in Niijima for our analysis. These samples were provided by M. Tsukui at the Faculty of Science, Chiba University, and T. Suzuki at the Faculty of Science, Tokyo Metropolitan University. We are indebted to K. Mannen, K. Tunematsu, A. Kato and C. Kobayashi for a critical reading of the manuscript. The suggestions of K. Mizuno of AIST also helped to clarify the article.

This study was carried out as one of the promotional projects of the Ministry of Education, Science, and Technology. We are extremely grateful to the people who helped us in our project.

\section{References}

Furusawa, A. (1995) Identification of tephra based on statistical analysis of refractive index and morphological classification of volcanic glass shards. Jour. Geol. Soc. Japan, 101, 123-133. (in Japanese)

Furusawa, A. (2003) Identification of tephras erupted from Iwate Volcano after the Toya ash falling. Jour. Geol. Soc. Japan, 109, 1-19. (in Japanese)

Hayakawa, Y. and Koyama, M. (1992) Eruptive history of the Higashi Izu monogenetic volcano field $1: 0$ 32ka. Bull. Volcanol. Soc. Japan, 37, 167-181. (in Japanese)

Kobayashi, M., Mannen, K., Okuno, M., Nakamura, T. and Hakamata, K. (2006) The Owakidani Tephra group: A newly discovered post-magmatic eruption product of Hakone Volcano, Japan. Bull. Volcanol. Soc. Japan, 51, 245-256. (in Japanese)
Koyama, M. (1998) Reevaluation of the 800-802 A.D. eruption of Fuji Volcano, Japan, and its influence on the ancient traffic network around the volcano, based on eruptive deposits and historical records. Bull. Volcanol. Soc. Japan, 43, 349-371. (in Japanese)

Koyama, M. and Hayakawa, Y. (1996) Syn- and Postcaldera eruptive history of Izu Oshima volcano based on tephra and loess stratigraphy. Journal of Geography, 105, 133-162. (in Japanese)

Machida, H. (1977) What about the volcanic ash talks to us - Natural history of volcano and plains -. Souju Shobou, 324p. (in Japanese)

Machida, H. and Arai, F. (1992) Atlas of tephra in and around Japan. University of Tokyo Press, 276p. (in Japanese)

Machida, H. and Arai, F. (2003) Atlas of tephra in and around Japan (Revised edition). University of Tokyo Press, 336p. (in Japanese)

Miyaji, N. (1988) History of younger Fuji Volcano. Jour. Geol. Soc. Japan, 94, 433-452. (in Japanese)

Miyaji, N., Endo, K., Togashi, S., and Uesugi, Y.(1992) Tephrochronological History of Mt. Fuji(C12), IGC Field Trip Guide Book, 29 $9^{\text {th }}$, Volcanoes and Geothermal Fields of Japan, 4, 75-109.

Nakano, S., Takada, A., Ishizuka, Y., Suzuki, Y., Chiba, T., Arai, K., Kobayashi, M. and Tajima, Y. (2007) Eruption ages of younger-stage lava flows, and older-stage pyroclastic cones at the northern foot of the Fuji volcano, Japan. Bull. Geol. Surv. Japan, 57, 387-407. (in Japanese)

Oki, Y. and Hakamata, K. (1975) Mystery of birth of Lake Ashi, Hakone volcano. National Land and Education, no.30 , 2-9. (in Japanese)

Saito, T., Takahashi, S. and Wada, H. (2003) ${ }^{14} \mathrm{C}$ ages of Omuroyama volcano, Izu Peninsula. Bull. Volcanol. Soc. Japan, 48, 215-219. (in Japanese)

Shimada, S., Sugihara, S. and Fukuoka, T. (1998) Distinction between Kozushima-Tenjosan tephra and Niijima Mukaiyama tephra by trace elements concentrations in volcanic glass. Abstracts, Japan Earth and Planetary Science Joint Meeting, 416p. (in Japanese)

Shizuoka Prefecture buried cultural property investigation laboratory (1991) Ikegaya ruins. Burial cultural property excavation investigation report of Seishin- bypass in 1990 fiscal year, 33p. (in Japanese)

Sugihara, S. (1984) Mineral description characteristics and eruptive ages of time-marker tephra in Naga Trench of Tanna fault. Chikyu monthly, no.6, 171-177. (in Japanese)

Sugihara, S. and Shimada, S. (1998) Trace element analysis of rhyolitic tephra discovered in Agetsuchi ruins. Shizuoka Prefecture buried cultural property investigation laboratory, Burial cultural property excavation investigation report, 107, Chapter of summary for Seishin- bypass, 169-174. (in Japanese)

Sugihara, S., Fukuoka, T. and Ookawara, R. (2001) Vol- 
canic Eruptions of Tenjouzan Volcano at Kozushima and Mukaiyama Volcano at Niijima, Izu Islands. Journal of Geography, 110, 94-105. (in Japanese)

Sugiuchi, Y. and Fukuoka, T. (2005) Tephrochronology of recent ( 1200 YBP) Mt. Fuji eruption history using rhyolitic tephra derived from outside Mt. Fuji Volcano. International Field Conference and Workshop on Tephrochronology and Volcanism: "Tephra Rush 2005”, INQUA Sub-Commission for Tephrochronology and Volcanism (SCOTAV).

Takada, A., Ishizuka, Y., Nakano, S., Kobayashi, M., Suzuki, Y., Arai, K. and Chiba, T. (2004) Evolution of eruption type of Fuji volcano - a preliminary report of trenching surveys at the franks of Fuji volcano. Chikyu monthly, no.48, 108-117. (in Japanese)

Takada, A., Ishizuka, Y., Nakano, S., Yamamoto, T., Kobayashi, M. and Suzuki, Y. (2007) Characteristic and evolution inferred from eruptive fissures of Fuji volcano, Japan. Fuji Volcano, edited by S. Aramaki, T. Fujii, S. Nakada, N. Miyaji, Yamanashi Institute of Environmental Science, 183-202. (in Japanese)

Takada, A. and Kobayashi, M. (2007) Eruptive history of flank eruptions by the trench survey at scoria cones on the southern flank of Fuji Volcano, Japan. Bull. Geol. Surv. Japan. 57, 329-356. (in Japanese)

Tsukui, M. and Suzuki, Y. (1998) Eruptive history of
Miyakejima volcano during the last 7000 years. Bull. Volcanol. Soc. Japan, 43, 149-166. (in Japanese)

Tsukui, M. (1999) Formation and eruptive history of Miyakejima volcano. Chikyu monthly, no.21, 399-405. (in Japanese)

Tsuya, H. (1968) Geology of Volcano Mt.Fuji. Explanatory text of geological map 1:50, 000 scale, Geological survey of Japan.

Uesugi, Y. (1990) Standard tephra columns for the eastward area of Volcano Fuji. Part 1: S-25 Y-141. Bull. Assoc. Kanto Quat. Res., 16, 3-28. (in Japanese)

Uesugi, Y. (1993) Tephrostratigraphic eruption forecasts of Fuji volcano, central Japan. The Quaternary Research, 32, 271-282. (in Japanese)

Uesugi, Y. (1998) History of Fuji Yoshida city, Volume 1: Chapter of historical materials, Nature and archeology. Fuji Yoshida city, 139-399. (in Japanese)

Uesugi, Y. (2003) Geographical guide book of Fuji volcano. The geological society of Japan Kanto Branch, 117p. (in Japanese)

Yamamoto, T., Takada, A., Ishizuka, Y. and Nakano, S. (2005) Chronology of the products of Fuji volcano based on new radiometric carbon ages. Bull. Volcanol. Soc. Japan, 50, 53-70. (in Japanese)

Received September 19, 2006

Accepted February 16, 2007

\section{神津島天上山テフラの同定とその層位に基づく富士火山の西暦 $700 １, 000$ 年の噴火史}

\section{小林 淳·高田 亮·中野 俊}

富士火山，伊豆半島周辺（箱根・東伊豆）及び伊豆諸島（三宅島・新島）で採取した，お打むね地表付近の風化火 山灰土中に含まれる珪長質降下テフラ起源の火山ガラスを対象にして, 電子・実体顕微鏡観察, 発泡度解析及び屈 折率測定等から給源テフラの同定を試みた。 火山ガラスの粒径分布, 特徴的に低い屈折率のほか, 発泡度の特徴等 から，これらの地域には神津島天上山テフラ (西暦838年) 起源の火山ガラスが広く分布することが明らかとなった。

神津島天上山テフラ起源の火山ガラスの特徵と, その火山ガラスが検出された層位との関係から,富士火山の側火 山起源噴出物（スコリア・溶岩流）の噴出年代の整理を試みた。その結果, 従来の炭素同位体年代測定では分離で きなかった， 9〜 10 世紀頃に頻発した富士火山の多くの噴火に対して，噴出年代の制約条件としての高精度な時間 軸を設定することができた。

本研究の結果, 神津島天上山テフラ起源の火山ガラスの濃集層準 (降灰層準) がより上位にあると判断した噴出物 は，「大淵スコリア」，「鑵子山スコリア」及び「西二ッ塚スコリア」（以上，南及び南東斜面）と，「鷹丸尾・檜丸尾 第 2 溶岩流」及び「御庭・奥庭第 2 噴火噴出物」（以上, 北及び北東斜面）である。一方, 神津島天上山テフラの降 灰層準よりがより下位にあると判断した噴出物は, 「不動沢溶岩流」,「大淵丸尾溶岩流」,「東臼塚南溶岩流」及び 「水ヶ塚丸尾溶岩」(以上, 南及び南東斜面）と, 「剣丸尾第 2 溶岩流」, 「貞観噴火噴出物（青木ヶ原溶岩流と長尾山 スコリア）」及び「天神・イガトノ噴火噴出物」（以上，北及び北東斜面）である。このほか，富士火山の東山腹周 辺のテフラ層序についても，神津島天上山テフラの降死層準との層位関係等に基づき新たに再検討し，「須走溶岩」 が神津島天上山テフラよりも上位にあることが明らかになった。 